\title{
Planejamento urbano para governança das cidades: a situação dos planos diretores dos municípios cearenses
}

\author{
Francisco Alberto de Castro Neto ${ }^{1}$ \\ Ana Elisa Pinheiro Campêlo de Castro \\ ${ }^{1}$ Secretaria das Cidades do Governo do Estado do Ceará, Fortaleza - CE, Brasil \\ ${ }^{2}$ Instituto de Planejamento de Fortaleza, Fortaleza - CE, Brasil
}

Este artigo tem o objetivo de identificar se os gestores dos municípios cearenses estão cumprindo a obrigação legal de desenvolver e instituir o principal instrumento de implementação da política de desenvolvimento urbano sustentável: o Plano Diretor. Para isso, foi realizado um levantamento bibliográfico das legislações vigentes pertinentes ao tema, e identificado, através da pesquisa Munic e dos sites das câmaras de vereadores locais, quais são os municípios cearenses que possuem Plano Diretor. Partindo desse levantamento, foram elencadas e georreferenciadas, no âmbito do Estado do Ceará, as categorias de cidades que têm obrigação de preparar e instituir o Plano Diretor, de acordo com a Lei no 10.257 , de 10 de julho de 2001, conhecida como Estatuto da Cidade. Em seguida, através da elaboração de tabelas e mapas, foi possível sobrepor informações das cidades que possuem Plano Diretor e das áreas relativas às categorias com vinculação legal para instituir esse instrumento. Com essa sobreposição, verificou-se a situação atual do planejamento urbano dos municípios cearenses, e constatou-se que a cultura de planejamento da política de desenvolvimento urbano ainda não foi implementada como fase fundamental da governança municipal em algumas das cidades cearenses.

Palavras-chaves: plano diretor, governança, municípios cearenses 


\section{Planificación urbana para la gobernanza de las ciudades: la situación de los planes directivos de los municipios del estado de Ceará}

Este artículo tiene como objetivo identificar si los administradores de los municipios del estado de Ceará están cumpliendo con la obligación legal de preparar e instituir el principal instrumento para implementar la política de desarrollo urbano sostenible: el Plan Maestro. Para ello, se realizó un relevamiento bibliográfico de la legislación vigente, pertinente al tema, e identificó, a través de la encuesta Munic y los sitios web de los ayuntamientos, que son los municipios de Ceará que cuentan con Plan Director. Con base en esta encuesta, las categorías de ciudades que tienen la obligación de elaborar e instituir el Plan Maestro fueron listadas y georreferenciadas en el ámbito del estado de Ceará, de conformidad con la Ley $n^{\circ} 10.257$, del 10 de julio de 2001, conocida como el Estatuto de la Ciudad. Luego, a través de la preparación de tablas y mapas, fue posible hacer la superposición de las informaciones de las ciudades que cuentan con un Plan Maestro y de las áreas relacionadas con categorías con vinculación legal para elaborar este instrumento. Con este traslapo se verificó la situación actual de la planificación urbana en los municipios de Ceará, y se encontró que la cultura de la planificación de la política de desarrollo urbano aún no se ha implementado como una fase fundamental de la gobernanza municipal en algunas de las ciudades de aquel estado.

Palabras clave: plan maestro, gobernanza, municipios de Ceará

\section{Urban planning for cities governance: the situation of the master plans of Ceará municipalities}

This article aims to identify whether the managers of Ceará municipalities are fulfilling the legal obligation to elaborate and institute the main instrument for implementing the sustainable urban development policy: The Master Plan. For this, a bibliographic survey of the current legislation, relevant to the theme, was carried out and identified, through the Munic survey and the websites of the local councils, which are the Ceara municipalities that have a Master Plan. Based on this survey, the categories of cities that have an obligation to prepare and institute the Master Plan were listed and georeferenced within the state of Ceará, in accordance with Law no. 10,257, of July 10, 2001, known as the Statute of the City. Then, through the elaboration of tables and maps, it was possible to superimpose information from the cities that have a Master Plan and from the areas related to categories with legal binding to elaborate this instrument. With this overlap, the current situation of urban planning in the municipalities of Ceará was verified. It was found that the culture of urban development policy planning has not yet been implemented as a fundamental phase of municipal governance in some of the cities of Ceará.

Keywords: master plan, governance, municipalities in Ceará 


\section{Introdução}

De acordo com o artigo 21, inciso XX, da Constituição Federal, compete à União instituir diretrizes para o desenvolvimento urbano, inclusive habitação, saneamento básico e transportes urbanos. Na mesma Carta Magna está previsto, no artigo 182 , parágrafos $1^{\circ}$ e $2^{\circ}$ :

Art. 182. A política de desenvolvimento urbano, executada pelo Poder Público municipal, conforme diretrizes gerais fixadas em lei, tem por objetivo ordenar o pleno desenvolvimento das funções sociais da cidade e garantir o bem-estar de seus habitantes.

$\S 1^{\circ}$ O Plano Diretor, aprovado pela Câmara Municipal, obrigatório para cidades com mais de vinte mil habitantes, é o instrumento básico da política de desenvolvimento e de expansão urbana.

$\S 2^{\circ}$ A propriedade urbana cumpre sua função social quando atende às exigências fundamentais de ordenação da cidade expressas no Plano Diretor.

Há quase duas décadas, foi instituída a obrigatoriedade do planejamento para o crescimento urbano ordenado das cidades brasileiras, mediante os artigos 39 a 42 da Lei Federal $\mathrm{n}^{\mathrm{o}}$ 10.257/01, o Estatuto da Cidade, que regulamentaram o artigo 182 da Constituição Federal de 1988, prevendo que o instrumento que normatiza o planejamento da política de desenvolvimento urbano, nas cidades, é o Plano Diretor.

O artigo 30, inciso VIII, da Constituição Federal, prevê que compete aos municípios promover, no que couber, adequado ordenamento territorial, mediante planejamento e controle do uso, do parcelamento e da ocupação do solo urbano. Assim, é competência da União legislar sobre diretrizes para o desenvolvimento urbano, e é competência do município legislar sobre o ordenamento territorial, considerando as especificidades regionais de cada cidade.

Conforme o artigo 39 do Estatuto da Cidade, a propriedade urbana cumpre sua função social quando atende às exigências fundamentais de ordenação da cidade, expressas no Plano Diretor, assegurando o atendimento das necessidades dos cidadãos quanto à qualidade de vida, à justiça social e ao desenvolvimento das atividades econômicas.

Assim, o Plano Diretor é uma lei municipal que trata da organização e ocupação territorial do município buscando integrar o uso do solo, habitação, saneamento e mobilidade urbana para, assim, assegurar uma melhor qualidade de vida a seus habitantes (CEARÁ, 2019).

O principal objetivo de um Plano Diretor é planejar o futuro da cidade, a partir 
do pensamento reflexivo sobre as funções exercidas no território (trabalho, moradia, lazer etc.), ordenando o pleno desenvolvimento das forças sociais existentes. Para tanto, é importante estabelecer como a propriedade cumprirá sua função social, de forma a garantir o acesso à terra urbanizada e regularizada, reconhecendo a todos os cidadãos o direito à moradia e aos serviços urbanos (BRASIL, 2020).

A nova agenda urbana trouxe também uma ampla ligação da questão urbana com os dezessete Objetivos do Desenvolvimento Sustentável (ODS) da Organização das Nações Unidas (ONU), além da inclusão do tema do direito à cidade. Em particular, o ODS 11 estabelece desafios importantes para políticos e gestores urbanos, sobretudo para uma realidade em que mais de $50 \%$ da população mundial vive em cidades (FAVARÃO; COSTA, 2018).

Nesse contexto, o Estatuto da Cidade trouxe uma nova forma de interação entre o poder público municipal e a população, alterando o modelo de governança das cidades, no processo de desenvolvimento e aprovação dos Planos Diretores. Esse novo modelo legitima a participação social, permitindo que a população possa opinar e decidir como a cidade deverá se desenvolver nos anos de vigência do Plano Diretor instituído.

Apesar disso, o que se percebe é que, até o momento, vários municípios brasileiros ainda não possuem seus Planos Diretores promulgados ou, ainda que possuam, os mesmos se encontram com prazo de revisão vencido. Com isso, esses municípios têm uma tendência a se expandirem territorialmente de forma desordenada, o que pode impactar negativamente o desenvolvimento das políticas públicas que são implementadas. No Ceará, a situação pode ser considerada mais grave, pois além de vários municípios ainda não terem elaborado tal planejamento, muitos dos municípios vêm enfrentando uma seca severa desde 2012 (CEARÁ, 2018), mostrando a necessidade de medidas urgentes para minimizar os impactos dessa condição climática através de um bom planejamento urbano.

Destaca-se que a falta do Plano Diretor traz uma série de problemas para o planejamento urbano e a governança municipal, acarretando: grande concentração populacional nas Regiões Metropolitanas; elevado déficit habitacional; esvaziamento das áreas centrais das cidades, com expansão desordenada das periferias, sem saneamento básico adequado, com degradação ambiental comprometendo o meio 
ambiente urbano e rural, violência e segregação sócio-espacial crescentes (MOREIRA, 2008). Caldas (2015) atribui o crescimento descontrolado e desorganizado das cidades à falta de planejamento urbano, ou seja, à falta de um Plano Diretor participativo e efetivo.

Com isso, este artigo procura colocar em debate a governança urbana, nos municípios brasileiros, em especial os cearenses, tendo em vista o papel de destaque que foi dado a essa temática na agenda pública, tanto em âmbito nacional quanto municipal e regional, principalmente em virtude dos conflitos sociais enfrentados nas grandes cidades e, principalmente, nas cidades com um maior número de famílias em situação de vulnerabilidade. E, para isso, o objetivo deste artigo é identificar se os gestores dos 184 municípios cearenses estão cumprindo a obrigação legal de preparar e instituir o principal instrumento de implementação da política de desenvolvimento urbano sustentável, de acordo com a Lei n ${ }^{\circ}$ 10.257/01 - Estatuto da Cidade.

\section{Metodologia}

Neste artigo, a análise foi realizada por meio do viés descritivo e quantitativo. Segundo Gil (1999), as pesquisas descritivas têm como objetivo primordial a definição das características de determinada população ou fenômeno, ou o estabelecimento de relações entre variáveis. São inúmeros os estudos que podem ser classificados sob esse título, sendo uma de suas características mais significativas a utilização de técnicas padronizadas de coleta de dados.

Segundo Fonseca (2002, p. 20), “a pesquisa quantitativa se centra na objetividade, influenciada pelo positivismo, e considera que a realidade só pode ser compreendida com base na análise de dados brutos, recolhidos com o auxílio de instrumentos padronizados e neutros". A pesquisa quantitativa recorre à linguagem matemática para descrever as causas de um fenômeno, as relações entre variáveis etc. Assim, cada etapa do presente estudo será descrita a seguir.

Esta pesquisa irá efetuar uma análise sobre os 184 municípios que compõem o Estado do Ceará ${ }^{1}$, buscando identificar quais são os municípios enquadrados, de acordo com o Estatuto da Cidade, no rol das cidades obrigadas a possuir Plano Diretor e quais

\footnotetext{
${ }^{1}$ O Ceará é uma das 27 unidades federativas do Brasil, situado no norte da Região Nordeste. Sua área total é de $148920,472 \mathrm{~km}^{2}$. A população do estado, em 2019, era de 9.132.078 habitantes, distribuída por 184 municípios (IBGE, 2019a).
} 
conseguiram preparar e instituir tal instrumento. Para isso, inicialmente foi feito um levantamento bibliográfico para entender quais os impactos que o novo planejamento urbano trouxe no sistema de governança das cidades, com o advento da Constituição Federal de 1988 e normativos posteriores, em especial, o Estatuto da Cidade. Em seguida, foi caracterizado o que é o Plano Diretor e quais as diretrizes impostas pelo Estatuto da Cidade aos municípios brasileiros, com enfoque nos cearenses.

No tópico seguinte, foi feita uma caracterização, de acordo com os dispositivos do Estatuto da Cidade, de quais municípios cearenses são obrigados a possuir Plano Diretor e, com base na Pesquisa de Informações Básicas Municipais (Munic)², elaborada pelo Instituto Brasileiro de Geografia e Estatística (IBGE), foi identificada qual a situação dos mesmos. Além disso, no dia 20 de fevereiro de 2020, foram validados, nos sites das câmaras municipais locais, se os municípios que informaram não possuir Plano Diretor, na pesquisa Munic, haviam preparado e aprovado o Plano Diretor municipal até aquela data. Com isso, foi identificado que os municípios de Lavras da Mangabeira, de Pacajus, de Jaguaribe, de Limoeiro do Norte e de Quixeré possuíam Plano Diretor e não constavam no levantamento da pesquisa Munic. A partir dessas informações, foi realizada, através da construção de tabelas e mapas, a sobreposição do território das cidades que possuem Plano Diretor e das áreas relativas às categorias com vinculação legal para organizar esse instrumento.

Por fim, foram emitidas as conclusões acerca do tema, evidenciando quais problemas podem ocorrer nos municípios que não possuem o planejamento urbano adequado.

\section{Evolução da governança pública para o planejamento urbano - pós CF 88 - Ceará}

Os acontecimentos políticos do final da década de 1980, no Brasil, representaram um momento de inflexão no que diz respeito à governança e às políticas voltadas para o território urbano nacional. Por um lado, a mudança institucional e

\footnotetext{
2 A Pesquisa de Informações Básicas Municipais faz o levantamento de dados que permitem o monitoramento e a estimativa de políticas locais, oferecendo reforço na construção de um material e de uma base de informações municipais de qualidade. Os estudos feitos pela Munic vêm desde 2005 com o intuito de mostrar a porcentagem de cidades que não cumprem a Lei n ${ }^{\circ}$ 10.257/2001 (FREITAS; BARBOSA, 2019).
} 
normativa, provocada pela Constituição Federal de 1988, delineou diretrizes regulatórias que passaram a incluir a participação democrática na definição das políticas públicas no país. Por outro lado, estabeleceu uma nova repartição de poderes entre os entes federativos, conferindo maior autonomia aos poderes entre os entes federativos, conferindo maior autonomia aos poderes políticos municipais da gestão e governança urbana (FAVARÃO; COSTA, 2018).

Percebe-se que diversos fenômenos marcaram os períodos posteriores à promulgação da Carta Magna, com caráter de mudanças, não só políticas, mas sociais, em virtude da grande mobilização gerada na sociedade para uma democratização das políticas públicas, ocasionando um impacto significativo na governança principalmente das cidades mais desenvolvidas e das metrópoles. Estas, com problemas de cunho social e de infraestrutura, em virtude das políticas adotadas em períodos anteriores.

Nesse sentido, após toda a pressão social pós-Constituição Federal, o Governo Federal promulgou o Estatuto da Cidade, em 2001, e posteriormente mudou sua estrutura organizacional, ampliando as oportunidade para a participação da população e dos demais entes federados, através da criação do Ministério das Cidades e mediante a institucionalização do Conselho das Cidades (ConCidades), ambos em 2003.

O Ministério das Cidades $^{3}$ foi criado com os objetivos de combater as desigualdades sociais, transformar as cidades em espaços mais humanizados e ampliar o acesso da população a moradia, saneamento e transporte. A ele foi delegado o desenvolvimento de importantes políticas públicas junto aos estados e municípios: habitação, saneamento, mobilidade e desenvolvimento urbano. Ou seja, o mesmo assumiu um papel institucional junto aos estados e municípios, para fomentar o desenvolvimento das políticas de sua competência nesses entes.

Já o Conselho das Cidades (ConCidades) foi criado com um papel mais social, agregando atores tanto políticos-institucionais, quanto pessoas da sociedade civil organizada, estimulando a participação e a discussão da população, e levando as principais demandas para a tomada de decisão dos gestores públicos. Assim, houve uma completa mudança no sistema de governança ${ }^{4}$ para a elaboração das políticas públicas

\footnotetext{
3 A partir de 2019 o Governo Federal promoveu uma nova reestruturação institucional, extinguindo o Ministério das Cidades e criando o Ministério do Desenvolvimento Regional (MDR), que assumiu as ações do extinto MCIDADES.

${ }^{4}$ Governança é o processo de tomada de decisão e o processo pelo qual as decisões são implementadas ou não. Pode ser visto como um conjunto de medidas das relações entre: governados e o governo. A noção
} 
urbanas, viabilizando uma participação mais efetiva da população, a partir de uma gestão participativa e da realização das conferências territoriais organizadas no âmbito do ConCidades.

Pouco tempo após a reorganização do Governo Federal, o Estado do Ceará promoveu uma reorganização similar, buscando alinhar a sua estrutura à do Governo Federal, promovendo a criação da Secretaria das Cidades, em 2007, e do Conselho Estadual das Cidades, em 2009.

A partir de 2007, com a criação da Secretaria das Cidades, através da Lei $n^{\circ}$ 13.875/2007, o Governo do Estado do Ceará vem buscando melhorar as condições de vida da população cearense mediante as políticas adotadas pelo Ministério das Cidades [extinto em 2019], atual Ministério do Desenvolvimento Regional. E, a partir de 21 de dezembro de 2009, com a institucionalização do Conselho Estadual das Cidades do Ceará $^{5}$, através da Lei $n^{\circ}$ 14.558/2009, o estado passou a ter uma instituição responsável por propor e deliberar sobre diretrizes e instrumentos para a formulação e implementação das políticas de gestão do solo urbano; de habitação; de saneamento ambiental; e de mobilidade e transporte urbano, em consonância com a Política Nacional de Desenvolvimento Urbano;, com as deliberações das Conferências Municipais, Estadual e Nacional das Cidades e com as resoluções do Conselho Estadual e Nacional das Cidades (CEARÁ, 2016).

Com essa evolução institucional, iniciada a partir da aprovação do Estatuto da Cidade, o planejamento urbano sofreu mudanças significativas nas fases de concepção, implementação e monitoramento. Nesse contexto, está previsto que essas fases, com relação ao Plano Diretor, devem ter uma participação social mais robusta e efetiva, dividindo assim a responsabilidade sobre as decisões que são tomadas no processo de planejamento da cidade. Aliado a isso, posteriormente, as reorganizações dos governos federal e estadual, e a criação dos seus respectivos Conselhos das Cidades, impulsionaram ainda mais a participação social no processo decisório das políticas públicas.

Com esse novo modelo de governança para o planejamento urbano e

de governança engloba as regras do jogo (as relações entre governantes e governados), os jogadores no jogo, e o "árbitro", se houver. Jogadores ativos são o Estado (governo e suas instituições) e elementos da sociedade civil (MCCALL; DUNN, 2012).

${ }^{5}$ O ConCidades/CE é composto por 29 (vinte e nove) membros titulares e respectivos suplentes, os quais, através de suas instituições/entidades, representam a Sociedade Civil e o Poder Público. 
considerando a grande dificuldade dos municípios cearenses em promulgarem os seus próprios planos diretores, o governo do estado, através da Secretaria das Cidades, realizou diversas ações para fomentar o desenvolvimento dos referidos planos. No entanto, mesmo com esse apoio, muitos municípios cearenses ainda não possuem esse plano devidamente formatado e regulamentado. Além disso, de acordo com Favarão e Costa (2018), até 2050, o contingente populacional urbano será maior que a população mundial atual, criando assim um desafio ao planejamento político e institucional voltado aos espaços das cidades.

\section{Diretrizes do Estatuto da Cidade para os Planos Diretores}

O Estatuto da Cidade (Lei $\mathrm{n}^{\circ}$ 10.257/01), que regulamenta o artigo 182 da Constituição Federal de 1988, oferece novas possibilidades para as gestões municipais. No artigo 40, o Estatuto elege o Plano Diretor como o instrumento que deverá orientar as diretrizes do desenvolvimento local, urbano e territorial, bem como articular as políticas setoriais de desenvolvimento urbano (habitação, saneamento ambiental, transporte e mobilidade, e controle do uso e ocupação do solo urbano). Para tanto, deveria ser considerada a totalidade do território municipal em suas dimensões urbana e rural (BITOUN; MIRANDA, 2009).

Ainda segundo Bitoun e Miranda (2009), a diversidade de situações urbanas nos municípios brasileiros exige uma ação coordenada no território. Um instrumento que pode programar todas as ações e políticas no território é o Plano Diretor. Diferentemente da concepção tradicional, que trabalhou historicamente o planejamento e a gestão em separado, a base para a efetividade das propostas e instrumentos preconizados pela reforma urbana é a instituição da gestão democrática da cidade como requisito fundamental.

Os planos diretores já foram alvos de diversas definições e conceituações, e suas características têm variado de município para município. Segundo Silva (2010, p. 134), o Plano Diretor é "plano, porque estabelece os objetivos a serem atingidos, o prazo em que estes devem ser alcançados [...], as atividades a serem executadas e quem deve executá-las. É diretor, porque fixa as diretrizes do desenvolvimento urbano do município”. De acordo com o Guia para Implementação pelos Municípios e Cidadãos, o Plano Diretor pode ser definido como "um conjunto de princípios e regras orientadoras 
da ação dos agentes que constroem e utilizam o espaço urbano" (BRASIL, 2002, p. 40).

No entanto, não basta conhecer a definição dele, é necessário saber quais municípios são obrigados a instituirem o mesmo. E, ao se mencionar a necessidade do Plano Diretor, a obrigatoriedade mais conhecida é a da elaboração para municípios com mais de vinte mil habitantes. Ocorre que o Estatuto da Cidade, em seu art. 41, tem a descrição de mais cinco hipóteses nas quais os municípios, ainda que não tenham mais de vinte mil habitantes, terão que preparar um Plano Diretor (BRASIL, 2001):
$[\ldots]$
II. integrantes de Regiões Metropolitanas e aglomerações urbanas;
III. onde o Poder Público municipal pretenda utilizar os instrumentos previstos no $\S 4^{\circ}$ do art. 182 da Constituição Federal;
IV. integrantes de áreas de especial interesse turístico;
V. inseridas na área de influência de empreendimentos ou atividades com significativo impacto ambiental de âmbito regional ou nacional.
VI. incluídas no cadastro nacional de Municípios com áreas suscetíveis à ocorrência de deslizamentos de grande impacto, inundações bruscas ou processos geológicos ou hidrológicos correlatos.

Vale ressaltar que o Estatuto da Cidade contém, em seu artigo 42, as disposições sobre o conteúdo mínimo obrigatório para a confecção e revisão do Plano Diretor:
Art. 42. O plano diretor deverá conter no mínimo:
I - a delimitação das áreas urbanas onde poderá ser aplicado o parcelamento, edificação ou utilização compulsórios, considerando a existência de infra- estrutura e de demanda para utilização, na forma do art. $5^{\circ}$ desta Lei; II - disposições requeridas pelos arts. 25, 28, 29, 32 e 35 desta Lei; III - sistema de acompanhamento e controle.

Em síntese, o escopo mínimo exigido no Estatuto da Cidade está descrito a seguir:

- delimitação das áreas urbanas onde poderá ser aplicado o parcelamento, edificação ou utilização compulsórios (Inciso I, art. 42);

- aplicação do direito de preempção (Inciso II, art.42; Art. 25);

- aplicação do coeficiente de aproveitamento (Inciso II, art.42; art. 28);

- aplicação de alteração do uso do solo (Inciso II, art.42; art. 29);

- delimitação de área para aplicação de operações urbanas consorciadas (Inciso II, art.42; art. 32);

- aplicação do direto de construir em outro local, ou alienar, mediante escritura pública, o direito de construir (Inciso II, art.42; art. 35);

- sistema de acompanhamento e controle (Inciso III, art. 42). 
Além do conteúdo previsto no artigo 42, o Plano Diretor dos municípios incluídos no cadastro nacional de municípios com áreas suscetíveis à ocorrência de deslizamentos de grande impacto, inundações bruscas ou processos geológicos ou hidrológicos correlatos deverá conter as informações dispostas no artigo 42-A. E, para os municípios que pretendam ampliar o seu perímetro urbano, os mesmos poderão prever o conteúdo mínimo exigido no artigo 42-B, ficando dispensados de preparação de projeto e lei específico para isso (BRASIL, 2012).

Nesse sentido, o Conselho Nacional das Cidades, mediante a Resolução $n^{\mathbf{o}} 34^{6}$, instituída em 1 de julho de 2005, e suas alterações, trouxe, de forma complementar, orientações mais claras sobre o contéudo mínimo de cada Plano:

I - As ações e medidas para assegurar o cumprimento das funções sociais da cidade, considerando o território rural e urbano;

II - As ações e medidas para assegurar o cumprimento da função social da propriedade urbana, tanto privada como pública;

III - Os objetivos, temas prioritários e estratégias para o desenvolvimento da cidade e para a reorganização territorial do município, considerando sua adequação aos espaços territoriais adjacentes;

IV - Os instrumentos da política urbana previstos pelo Estatuto da Cidade que serão utilizados para concretizar os objetivos e as estratégias estabelecidas pelo Plano Diretor; e o sistema de acompanhamento e controle visando à execução e implementação do Plano Diretor.

Portanto, durante o desenvolvimento do Plano Diretor, deverão ser observadas as diretrizes impostas no Estatuto da Cidade, bem como as orientações do Conselho Nacional das Cidades. Seguindo essas orientações, o Plano Diretor torna-se uma ferramenta importante da participação da população no planejamento e traz diretrizes para que a administração pública possa gerir o ordenamento territorial de forma mais coerente com as necessidades de desenvolvimento da cidade.

\section{Ceará e a situação do planejamento urbano dos seus municípios}

Como apresentado anteriormente, atualmente são seis as hipóteses em que um determinado município brasileiro está obrigado a ter o seu Plano Diretor. E o munícipe, o Ministério Público ou outro legitimado poderá exigir o mesmo perante o Poder Judiciário.

\footnotetext{
${ }^{6}$ Posteriormente, o Conselho Nacional das Cidades publicou a Resolução n ${ }^{\circ}$ 22/2006 para orientar os municípios inseridos em áreas de influência de empreendimentos ou atividades com significativo impacto ambiental, de âmbito regional ou nacional.
} 
Apesar dessa obrigação legal, para Dias (2011), a implementação dos instrumentos do Estatuto da Cidade, através dos Planos Diretores, enfrenta vários desafios:

\begin{abstract}
Aprovação nas Câmaras Municipais da regulamentação dos instrumentos, que na sua maioria ficaram para ser aprovados posteriormente à aprovação do Plano Diretor, já que essas regulamentações contrariam interesses financeiros de parte da produção imobiliária;

Impasse gerado pelas disputas partidárias e ideológicas que pode ser exemplificado no fato de diversas vezes o plano, ou sua revisão, não serem enviados à Câmara Municipal por conta do momento de transição entre diferentes gestões ou onde as forças entre o executivo e o legislativo não se mostravam favoráveis ao anteprojeto de lei;

Falta de capacitação técnica nas administraçãoes públicas locais, para a regulamentação e utilização disponibilizados pelo Estatuto da Cidade;

Descontinuidade das administrações públicas, devido a diferentes interesses e pressões para mudanças pontuais que satisfaçam novos interesses;

Falta de atualização de toda a legislação urbanística dentro dos padrões e finalidades de se produzir a função social da cidade e da propriedade, bem como a gestão democrática de uma cidade (DIAS, 2011, p. 52).
\end{abstract}

Já para Goulart et al. (2015), os municípios apresentam muitas dificuldades para implementar seus Planos Diretores. A maioria não tem estrutura administrativa adequada para o exercício do planejamento urbano, no que se refere aos recursos técnicos, humanos, tecnológicos e materiais, sem contar a baixa difusão dos conselhos de participação e controle social voltados para uma cultura participativa de construção e implantação da política de desenvolvimento.

E, para Santos Junior e Montandon (2011, p.36), os desafios enfrentados para a implantação dos Planos Diretores podem ser atribuídos a “[...] poucos recursos técnicos e humanos para a elaboração de mapas e demais peças técnicas, inexistência ou precariedade de cadastros e de informações básicas sobre o território, reduzido tempo para o processo de construção do plano, descaso ou desinteresse dos gestores e do legislativo com o processo de preparação ou aprovação do Plano Diretor".

Ressalta-se que, por meio do Plano Diretor, é possível integrar os demais instrumentos de planejamento que, quando implementados, farão com que se cumpra a função social da cidade e da propriedade urbana.

A seguir, é apresentada uma discussão mais detalhada de cada uma das seis situações, previstas no Estatuto das Cidades, em que os municípios cearenses (e brasileiros) estão obrigados a possuir o Plano Diretor, e a situação atual de cada um, a partir das informações levantadas conforme metodologia descrita anteriormente e dados 
compilados no Apêndice A.

\subsection{Municípios cearenses com mais de 20 mil habitantes}

De acordo com o Instituto Brasileiro de Geografia e Estatística - IBGE (2019a), dos 184 municípios cearenses, 101 municípios possuem mais de 20 mil habitantes, considerando as projeções para o ano de 2019, a partir do último Censo Demográfico realizado em $2010^{7}$ (Tabela 1 ).

Tabela 1 - População dos municípios cearenses x Plano Diretor

\begin{tabular}{|l|c|c|c|c|c|}
\hline \multirow{2}{*}{$\begin{array}{c}\text { População do } \\
\text { município (habitantes) }\end{array}$} & $\begin{array}{c}\text { Total de } \\
\text { municípios }\end{array}$ & \multicolumn{3}{|c|}{ Possui Plano Diretor } & $\begin{array}{c}\text { Não possui } \\
\text { Plano Diretor }\end{array}$ \\
\cline { 3 - 5 } & 9 & 4 & 5 & 9 & 0 \\
\hline Maior que 100 mil & 4 & 1 & 3 & 4 & 0 \\
\hline $80 \mathrm{mil}-100 \mathrm{mil}$ & 14 & 6 & 8 & 14 & 0 \\
\hline $60 \mathrm{mil}-80 \mathrm{mil}$ & 21 & 10 & 6 & 16 & 5 \\
\hline $40 \mathrm{mil}-60 \mathrm{mil}$ & 53 & 11 & 27 & 38 & 15 \\
\hline $20 \mathrm{mil}-40 \mathrm{mil}$ & $\mathbf{1 0 1}$ & $\mathbf{3 2}$ & $\mathbf{4 9}$ & $\mathbf{8 1}$ & $\mathbf{2 0}$ \\
\hline Sub-total & 83 & 6 & 9 & 15 & 68 \\
\hline Menor que 20 mil & $\mathbf{1 8 4}$ & $\mathbf{3 8}$ & $\mathbf{5 8}$ & $\mathbf{9 6}$ & $\mathbf{8 8}$ \\
\hline Total & & & & & \\
\hline
\end{tabular}

Fonte: IBGE (2019a, 2019b).

Desses 101 municípios que possuem mais de 20 mil habitantes, apenas 81 municípios possuem o Plano Diretor instituídos, ou seja, apenas $80 \%$ desses municípios possuem os planos instituídos (Figura 1).

\footnotetext{
${ }^{7}$ A partir de 2021 existe a previsão da efetuação de um novo Censo, portanto essa informação deverá ser averiguada mais detalhadamente uma vez que os dados terão uma precisão maior. No entanto, em virtude da pandemia relacionada ao COVID-19 esse Censo ainda não tem previsão exata para o seu início e término.
} 


\section{Figura 1 - Municípios cearenses com mais de 20 mil habitantes X Plano Diretor}

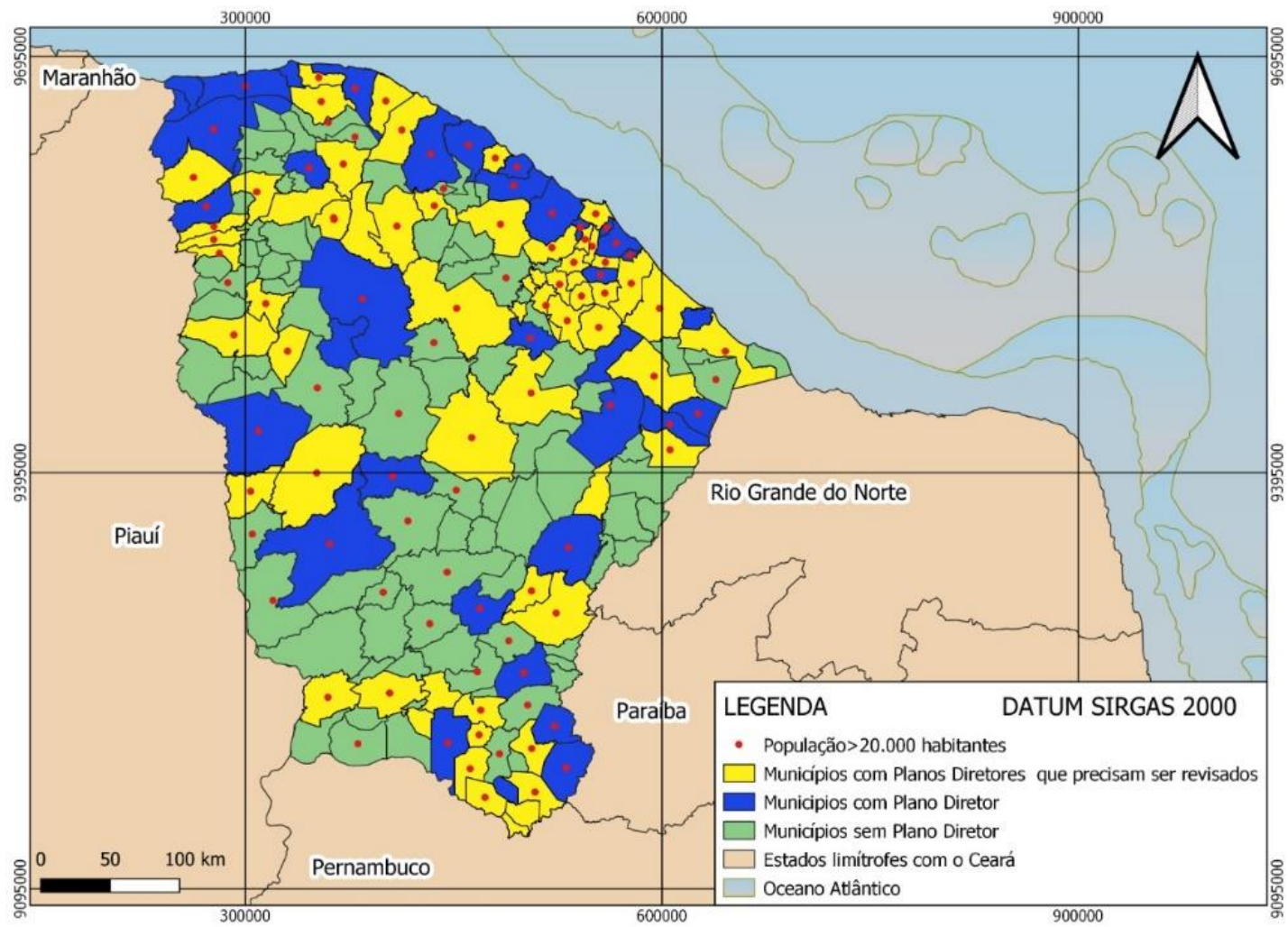

Fonte: elaboração própria a partir de IBGE (2019a, 2019b).

Cabe destacar que, mesmo dentre os 81 municípios com mais de 20 mil habitantes que possuem Plano Diretor, 49 municípios (60\%) necessitam revisar ${ }^{8}$ seus planos, pois foram aprovados há mais de 10 anos.

\subsection{Municípios integrantes de Regiões Metropolitanas e aglomerações urbanas}

O marco conceitual da formação das metrópoles, no Brasil, historicamente se iniciou a partir da década de 1960, com a discussão acerca de problemas na urbanização dessas regiões. Conforme explica Souza (2007), nessa época, devido aos modos de governança das metrópoles, pode-se dizer que houve certo fracasso nesse tipo de arranjo político e administrativo-legal. Tal situação é atribuída a dois fatores fundamentais, mediante a análise feita por ele. Como primeiro fator, os gestores municipais agiam de maneira reticente, sem querer aceitar, ou dar satisfação, a um poder acima do que lhes era atribuído, demonstrando, com isso, a insatisfação de estar na dependência do

\footnotetext{
${ }^{8} \mathrm{O}$ Estatuto da Cidade, no $\S 3^{\circ}$ do seu artigo 30, determina que, pelo menos a cada 10 (dez) anos, os planos diretores devem ser revistos. Para este artigo, foram considerados como necessitados de atualização os planos diretores aprovados antes de 2010.
} 
governo central para que fosse assegurado o seu funcionamento. Como segundo fator, está o modelo utilizado para implementar essas Regiões Metropolitanas, autoritário, sem permitir aos municípios a escolha de assim se constituírem, o que era agravado com a elaboração de uma governança de forma rígida, destituída da participação da população local envolvida.

A partir de então, o reconhecimento legal da formação da Região Metropolitana se confirmou, no ano de 1973, com a promulgação da Lei Federal Complementar $n^{\circ}$ 14/1973, que estabeleceu as oito primeiras Regiões Metropolitanas do Brasil, sendo elas de: São Paulo, Belo Horizonte, Porto Alegre, Recife, Salvador, Curitiba, Belém e Fortaleza.

Atualmente, no Estado do Ceará, existem 3 Regiões Metropolitanas: de Fortaleza $^{9}$, de Sobral $^{10}$ e do Cariri ${ }^{11}$. No total, essas três regiões possuem 46 municípios.

Vale ressaltar que, para as Regiões Metropolitanas, foi instituído, em 2015, através da Lei no 13.089, o Estatuto da Metrópole, que traz diretrizes gerais para planejamento, gestão e execução das funções públicas de interesse comum nessas Regiões Metropolitanas e aglomerações urbanas instituídas pelo Estado. Essa lei também estabeleceu normas gerais sobre os Planos de Desenvolvimento Urbanos Integrados (PDUIs) e outros instrumentos de governança interfederativa.

Segundo Valery e Braga Junior (2015), como já existiam outras normas que tratavam das políticas e de desenvolvimento urbano, seja no âmbito municipal, estadual ou federal, o Estatuto da Metrópole foi editado em consonância com aquelas, visando preencher as lacunas porventura existentes, principalmente no Estatuto da Cidade, que, não obstante tenha disposto preciosos instrumentos para o planejamento municipal, o uso social da propriedade urbana e gestão democrática das cidades, deixou a dimensão do desenvolvimento "regional-urbano" ainda ausente, mesmo tendo considerado as especificidades das Regiões Metropolitanas e aglomerações urbanas, enquanto

\footnotetext{
${ }^{9}$ A Região Metropolitana de Fortaleza desde 2014, quando sofreu a sua última alteração, conta com 19 municípios: Aquiraz, Cascavel, Caucaia, Chorozinho, Eusébio, Fortaleza, Guaiuba, Horizonte, Itaitinga, Maracanaú, Maranguape, Pacajus, Pacatuba, Paracuru, Paraipaba, Pindoretama, São Gonçalo do Amarante, São Luís do Curu e Trairi (IBGE, 2019a).

10 A Região Metropolitana de Sobral foi constituída em 2016 e é formada por 18 municípios: Sobral (sede), Massapê, Senador Sá, Pires Ferreira, Santana do Acaraú, Forquilha, Coreaú, Moraújo, Groaíras, Reriutaba, Varjota, Cariré, Pacujá, Graça, Frecheirinha, Mucambo, Meruoca e Alcântaras (IBGE, 2019a). 11 A Região Metropolitana do Cariri foi estabelecida em 2009, sendo formada por 9 municípios: os municípios do Crajubar (Crato, Juazeiro do Norte e Barbalha), além de Caririaçu, Farias Brito, Jardim, Missão Velha, Nova Olinda, Santana do Cariri (IBGE, 2019a).
} 
categorias institucionais, em algumas de suas disposições.

Destaca-se que a obrigatoriedade de aprovação do Plano de Desenvolvimento Urbano Integrado das Regiões Metropolitanas não exime os municípios integrantes dessas regiões da formulação dos seus respectivos Planos Diretores, os quais deverão estar compatibilizados.

No Estado do Ceará, as Regiões Metropolitanas do Cariri e de Sobral possuem os seus Planos de Desenvolvimento Urbano Integrados (PDUIs) efetivados ${ }^{12}$. No entanto, o PDUI da Região Metropolitana de Fortaleza ainda não foi iniciado.

Assim, como mencionado anteriormente, a existência ou não dos PDUIs não exime os municípios de prepararem seus próprios Planos Diretores. Dessa forma, dos 46 municípios pertencentes às três Regiões Metropolitanas do Estado do Ceará, 30 municípios possuem Plano Diretor promulgado, ou seja, 65\% (Tabela 2).

\section{Tabela 2 - Municípios cearenses em Regiões Metropolitanas x Plano Diretor}

\begin{tabular}{|l|r|r|r|r|}
\hline \multirow{2}{*}{\multicolumn{1}{c|}{ Região Metropolitana }} & \multicolumn{2}{c|}{ Possui Plano Diretor } & \multicolumn{1}{c|}{$\begin{array}{c}\text { Não possui } \\
\text { Plano Diretor }\end{array}$} \\
\cline { 2 - 5 } & Atualizado & Desatualizado & Total & 10 \\
\hline Região Metropolitana de Fortaleza & 8 & 10 & 7 & 2 \\
\hline Região Metropolitana do Cariri & 1 & 6 & 5 & 13 \\
\hline Região Metropolitana de Sobral & 1 & 4 & 66 & 72 \\
\hline Fora das Regiões Metropolitanas & 28 & 38 & $\mathbf{9 6}$ & $\mathbf{8 8}$ \\
\hline Total & $\mathbf{3 8}$ & $\mathbf{5 8}$ & \\
\hline
\end{tabular}

Fonte: IBGE (2019a, 2019b).

As informações da Tabela 2 foram distribuídas espacialmente na Figura 2 para uma melhor compreensão.

12 Os Planos de Desenvolvimento Urbano Integrado das Regiões Metropolitanas do Cariri e de Sobral foram desenvolvidos pela Secretaria das Cidades do Estado do Ceará em parceria com as prefeituras municipais de cada região. 


\section{Figura 2 - Municípios cearenses - Regiões Metropolitanas X Plano Diretor}

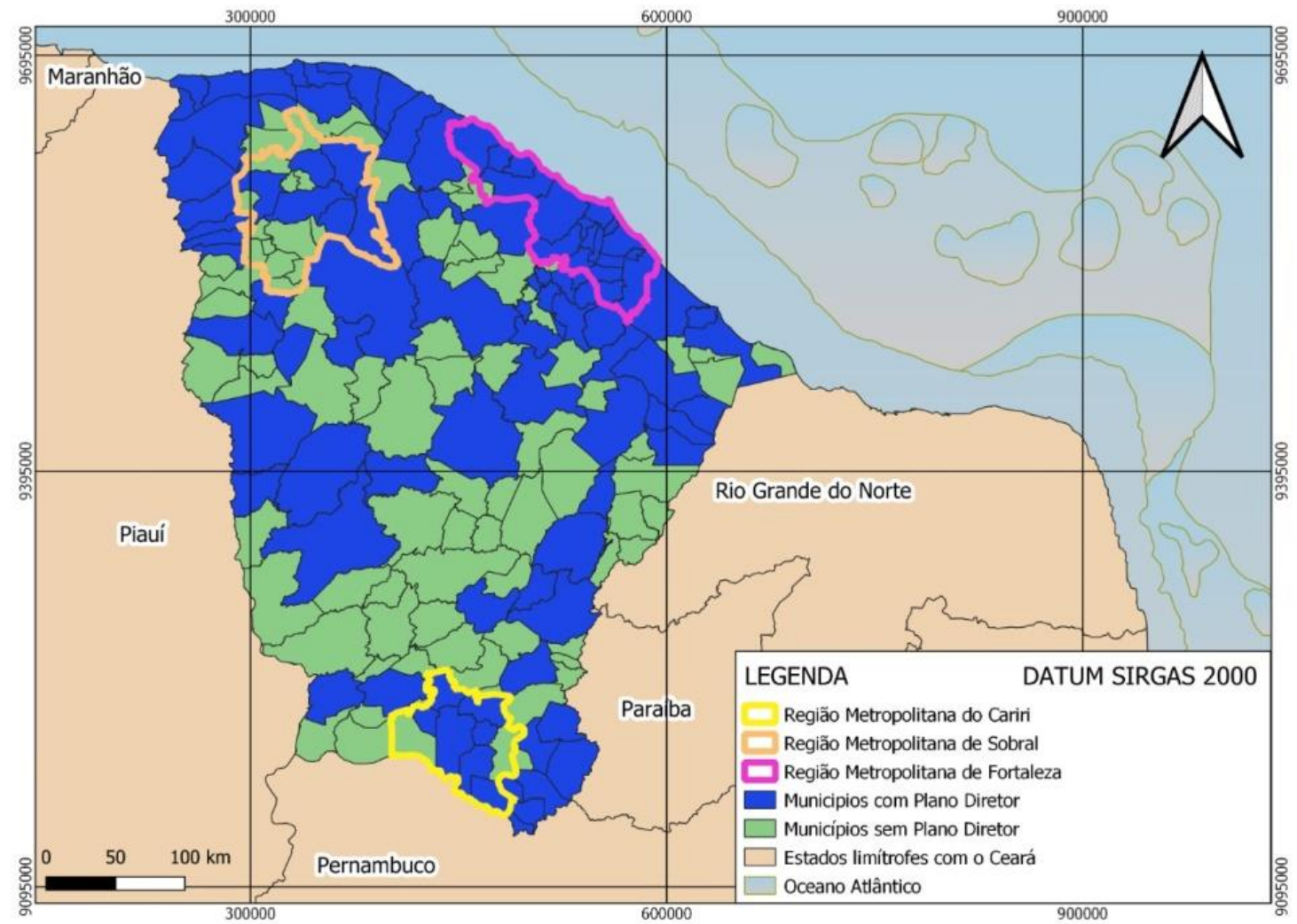

Fonte: elaboração própria a partir de IBGE (2019a, 2019b).

Cabe destacar que, mesmo dentre os 30 municípios que possuem Plano Diretor, 20 municípios (67\%) necessitam revisar seus planos, pois foram instituídos há mais de 10 anos.

\subsection{Municípios onde o Poder Público municipal pretenda utilizar os instrumentos previstos no $\$ 40$ do art. 182 da Constituição Federal}

Segundo o $\S^{\circ}$ do art. 182 da Constituição Federal:

É facultado ao poder público municipal, mediante lei específica para área incluída no Plano Diretor, exigir, nos termos da lei federal, do proprietário do solo urbano não edificado, subutilizado ou não utilizado que promova seu adequado aproveitamento, sob pena, sucessivamente, de:

I - parcelamento ou edificação compulsórios;

II - imposto sobre a propriedade predial e territorial urbana progressivo no tempo;

III - desapropriação com pagamento mediante títulos da dívida pública de emissão previamente aprovada pelo Senado Federal, com prazo de resgate de até dez anos, em parcelas anuais, iguais e sucessivas, assegurados o valor real da indenização e os juros legais.

Verifica-se, portanto, que, para os gestores municipais, que pretendam estabelecer o controle urbano e o consequente cumprimento da função social da 
propriedade urbana, de forma a garantir a utilização adequada do solo urbano, é necessário que os instrumentos elencados, no referido artigo, estejam previstos no Plano Diretor, já que a área onde esses instrumentos serão implantados deverá estar definida na lei que normatiza tal plano.

É importante salientar que, apesar de a aplicação desses instrumentos ser discricionária, o cumprimento da função social da cidade é vinculativo, ou seja, este último não é decisão da gestão municipal, tem que necessariamente ocorrer. Assim, para efeito da análise em questão, esse item não será contabilizado como obrigatório, já que se trata da aplicação discricionária de instrumentos no âmbito de um Plano Diretor.

\subsection{Municípios integrantes de áreas de especial interesse turístico}

Conforme o artigo $3^{\circ}$ da Lei $\mathrm{n}^{\circ}$ 6.513, de 20 de dezembro de 1977, as áreas especiais de interesse turístico são trechos contínuos do território nacional, inclusive suas águas territoriais, a serem preservados e valorizados no sentido cultural e natural, e destinados à realização de planos e projetos de desenvolvimento turístico.

Complementarmente, segundo o Decreto $\mathrm{n}^{\circ}$ 86.176, de 6 de julho de 1981, as áreas Especiais de lnteresse Turístico classificam-se em:

I - Prioritárias: áreas de alta potencialidade turística, que devam ou possam ser objeto de planos ou programas de desenvolvimento turístico, em virtude de:

a) ocorrência ou iminência de expressivos fluxos de turistas e visitantes;

b) existência de infraestrutura turística e urbana satisfatória, ou possibilidade de sua implantação em condições a serem fixadas pelo Conselho Nacional de Turismo - CNTur, por proposta da EMBRATUR;

c) necessidade da realização de planos e projetos de preservação ou recuperação dos Locais de Interesse Turístico nelas incluídos;

d) realização presente ou iminente de obras públicas ou privadas, que permitam ou assegurem o acesso à área, ou a criação da infraestrutura mencionada na alínea b;

e) conveniência de prevenir ou corrigir eventuais distorções do uso do solo, causadas pela realização presente ou iminente de obras públicas ou privadas, ou pelo parcelamento e ocupação do solo.

II - De Reserva: áreas de elevada potencialidade turística, cujo aproveitamento deva ficar na dependência:

a) da implantação dos equipamentos de infraestrutura indispensáveis;

b) da efetivação de medidas que assegurem a preservação do equilíbrio ambiental e proteção ao patrimônio cultural e natural nelas existentes;

c) de providências que permitam regular, de maneira compatível com a alínea precedente, os fluxos de turistas e visitantes e as atividades, obras e serviços permissíveis.

Ao analisar as legislações mencionadas anteriormente, verifica-se que muitos 
critérios apresentados são subjetivos e, passado vários anos, houve pouca aplicabilidade das mesmas. Ademais, cabe ressaltar que, atualmente, a instituição que seria a principal articuladora das referidas leis, o Instituto Brasileiro de Turismo (Embratur) não acumula mais a função de planejamento, que foi transferida para o Ministério do Turismo (MTur).

Desde a sua criação, até o presente momento, não foi identificado nenhum município do território nacional designado como Área Especial de Interesse Turístico. Destaca-se que a criação de “Áreas Especiais de Interesse Turístico" e "Locais de Interesse Turístico" não deve ser confundida com a caracterização de cidade ou município turístico.

A regulamentação de "Áreas Especiais" e de "Locais de Interesse Turístico" contribuiria, diretamente, para alcançar a produção de um espaço urbano e turístico capaz de satisfazer as necessidades de moradores e visitantes, com características de sustentabilidade, e não um desenvolvimento turístico-urbano produzido segundo a lógica que atende, preferencialmente, aos interesses imediatos dos principais agentes produtores desse espaço: o poder público, empresários do segmento turístico e do setor imobiliário (HARVEY, 1980).

Apesar de não ter sido identificado nenhum município cearense como sendo pertencente a Área Especial de Interesse Turístico, a partir de 2008, com a promulgação da Lei $\mathrm{n}^{0} 11.771 / 2008$ (Lei do Turismo), foram disponibilizadas ferramentas para o monitoramento e o aperfeiçoamento das medidas necessárias para o desenvolvimento turístico dos municípios brasileiros. Uma dessas ferramentas é o Mapa do Turismo ${ }^{13}$, que apresenta os municípios brasileiros considerados como grandes polos atrativos para o turismo nacional.

Portanto, apesar de não existir o conhecimento de nenhum município cearense pertencente à Área Especial de Interesse Turístico, serão considerados aqui os municípios que foram definidos no Mapa do Turismo como de potencial turístico para as suas regiões, conforme apresentado na Tabela 3.

\footnotetext{
${ }^{13}$ O Mapa do Turismo Brasileiro é o instrumento instituído pela Portaria MTur $n^{\circ} 313$, de 3 de dezembro de 2013, atualizada no âmbito do Programa de Regionalização do Turismo que orienta a atuação do Ministério do Turismo no desenvolvimento das políticas públicas. É o Mapa do Turismo Brasileiro que define a área - o recorte territorial - que deve ser trabalhada prioritariamente pelo referido ministério (BRASIL, 2015b).
} 
Tabela 3 - Municípios cearenses em áreas turísticas X Plano Diretor

\begin{tabular}{|l|c|c|c|c|c|}
\hline \multirow{2}{*}{ Situação do município } & \multirow{2}{*}{$\begin{array}{c}\text { Total de } \\
\text { municípios }\end{array}$} & \multicolumn{3}{c|}{ Possui Plano Diretor } & \multirow{2}{*}{$\begin{array}{c}\text { Não possui } \\
\text { Plano Diretor }\end{array}$} \\
\cline { 3 - 6 } & Atualizado & Desatualizado & Total & Plano em área turística \\
Situado & 68 & 24 & 34 & 58 & 10 \\
\hline Não situado em área turística & 116 & 13 & 25 & 38 & 78 \\
\hline Total & $\mathbf{1 8 4}$ & $\mathbf{3 7}$ & $\mathbf{5 9}$ & $\mathbf{9 6}$ & $\mathbf{8 8}$ \\
\hline
\end{tabular}

Fonte: Brasil (2016) e IBGE (2019b).

Dessa forma, conforme apresentado na Tabela 3, no Estado do Ceará foram

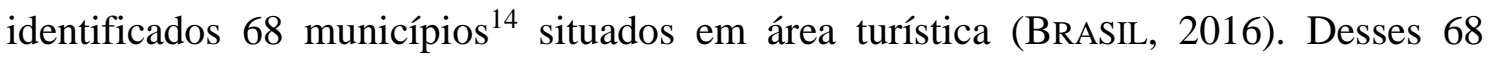
municípios, 58 municípios possuem Plano Diretor (85\%), ver Figura 3.

\section{Figura 3 - Municípios cearenses - áreas turísticas X Plano Diretor}

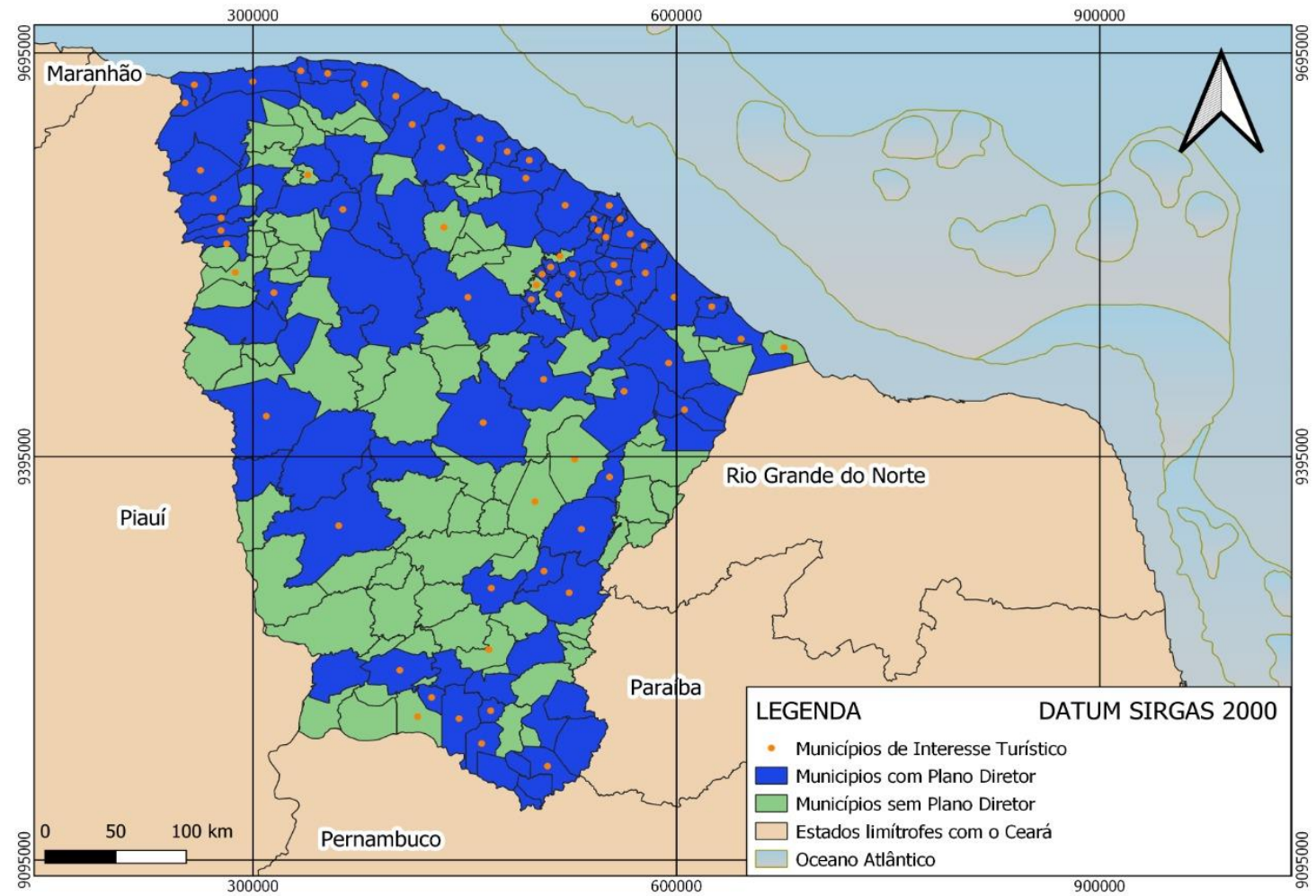

Fonte: elaboração própria a partir de Brasil (2016); IBGE (2019b).

Ressalta-se que, mesmo dentre os 58 municípios que possuem Plano Diretor, 34 municípios (58\%) necessitam revisar seus planos, pois foram instituídos há mais de 10 anos.

14 Os municípios que compõem o Mapa do Turismo Brasileiro 2016 foram estabelecidos através dos critérios instituído pela Portaria no 205, de 09 de dezembro de 2015. 
5.5. Municípios cearenses inseridos na área de influência de empreendimentos ou atividades com significativo impacto ambiental de âmbito regional ou nacional

No caso da realização de empreendimentos ou atividades enquadradas no inciso V do caput do art. 41 do Estatuto da Cidade, os recursos técnicos e financeiros para a confecção do Plano Diretor estarão inseridos entre as medidas de compensação adotadas. Apesar da disposição legal, a definição precisa sobre quais empreendimentos enquadram-se no critério do inciso destacado nunca foi efetuada. Não foi explicitado, nem na lei, nem em disposições posteriores, qual a unidade de medida para determinação do impacto ambiental de um dado empreendimento, bem como sua escala (regional/nacional). Complementarmente, também não se determinou se a compensação financeira apontada seria advinda de uma categoria nova e específica ou poderia estar incluída nas já existentes e tradicionais compensações, quando da elaboração dos licenciamentos e Estudos de Impacto Ambiental (ALMEIDA, 2017).

Nesse contexto, a legislação mostrou-se insuficiente e de aplicação complicada por parte dos municípios. Dessa forma, o Conselho Nacional das Cidades publicou, em 06 de dezembro de 2006, a Resolução Recomendada $\mathrm{n}^{\circ} 22$, com objetivo de dar maior clareza sobre os procedimentos a serem adotados para garantir o financiamento dos planos diretores pelos empreendedores.

Portanto, considerando o disposto na Resolução mencionada anteriormente e os empreendimentos iniciados após a promulgação do Estatuto da Cidade, no Estado do Ceará, foram identificadas quatro grandes intervenções com significativo impacto ambiental de âmbito regional ou nacional: Ferrovia TransNordestina, Transposição do Rio São Francisco, Canal da Integração (Eixão das Águas) e o Cinturão das Águas.

A Ferrovia TransNordestina ${ }^{15}$ é uma ferrovia projetada para ligar o Porto do Pecém, no Ceará, ao Porto de Suape, em Pernambuco, além do cerrado do Piauí, com extensão total de $1.753 \mathrm{~km}$ (BRASIL, 2017).

A Transposição do Rio São Francisco ${ }^{16}$ é um projeto de deslocamento de parte das águas do Rio São Francisco. A obra prevê a construção de mais de 700 quilômetros de canais de concreto em dois grandes eixos (norte e leste) ao longo do território dos

\footnotetext{
${ }^{15}$ A Ferrovia Transnordestina foi iniciada em 2006; no entanto, atualmente ainda não foi concluída e está sem previsão de término, com previsão para perpassar 26 municípios cearenses.

16 A transposição do Rio São Francisco foi iniciada em 2007, no entanto, atualmente ainda não foi concluída. Teve o trecho que se conecta ao Ceará concluído em 2020, perpassando 5 municípios cearenses.
} 
Estados de Pernambuco, Paraíba, Ceará e Rio Grande do Norte (CEARÁ, 2018).

O Canal da Integração ou Eixão das Águas ${ }^{17}$ é um empreendimento de grande porte que irá ajudar na segurança hídrica do Estado do Ceará, realizando a transposição das águas do Açude Castanhão para a Região Metropolitana de Fortaleza (RMF), reforçando o abastecimento da população e da indústria (CEARÁ, 2018).

O Cinturão das Águas do Ceará ${ }^{18}$ (CAC) é um empreendimento que irá viabilizar uma maior capilaridade das vazões transpostas pelo Projeto de Integração do Rio São Francisco em território cearense, levando a água da transposição para 46 municípios cearenses através de canais, formando um cinturão ao longo do estado (CEARÁ, 2018).

Percebe-se que, em virtude da condição climática enfrentada pelo Estado do Ceará, a maior parte dos principais empreendimentos realizados no seu território são voltados para a segurança hídrica, conforme Tabela 4.

Tabela 4 - Municípios cearenses em áreas de influência de empreendimentos ou atividades com significativo impacto ambiental de âmbito regional ou nacional $X$ Plano Diretor

\begin{tabular}{|c|c|c|c|c|c|}
\hline \multirow{2}{*}{ Situação do Município } & \multirow{2}{*}{$\begin{array}{c}\text { Total de } \\
\text { Municípios }\end{array}$} & \multicolumn{3}{|c|}{ Possui Plano Diretor } & \multirow{2}{*}{$\begin{array}{c}\text { Não Possui } \\
\text { Plano } \\
\text { Diretor } \\
\end{array}$} \\
\hline & & Atualizado & Desatualizado & Total & \\
\hline $\begin{array}{l}\text { Situado em área de } \\
\text { empreendimento de grande impacto }\end{array}$ & 73 & 18 & 32 & 50 & 23 \\
\hline $\begin{array}{l}\text { Não situado em área de } \\
\text { empreendimento de grande impacto }\end{array}$ & 111 & 19 & 27 & 46 & 65 \\
\hline Total & 184 & 37 & 59 & 96 & 88 \\
\hline
\end{tabular}

Fonte: Brasil (2017, 2019b) e Ceará (2018).

Considerando os empreendimentos de impacto regional ou nacional, no Estado do Ceará, conforme apresentado na Tabela 4, 73 municípios deveriam possuir planos diretores que poderiam ser custeados por esses empreendimentos em questão. No entanto, verifica-se que apenas 50 municípios possuem Plano Diretor, ou seja, 68\% (Figura 4).

${ }^{17}$ O Canal da Integração (Eixão das Águas) teve sua primeira etapa concluída em 2013, no entanto, a sua conclusão total ainda não foi efetivada. $\mathrm{O}$ mesmo, quando concluído, irá perpassar 9 municípios cearenses (CEARÁ, 2018).

${ }^{18}$ O Cinturão das Águas do Ceará (CAC) não tem previsão para conclusão da sua implantação total. Quando concluído, deverá perpassar por 46 municípios cearenses (CEARÁ, 2018). 
Figura 4 - Municípios cearenses - atividades com significativo impacto ambiental de âmbito regional ou nacional X Plano Diretor

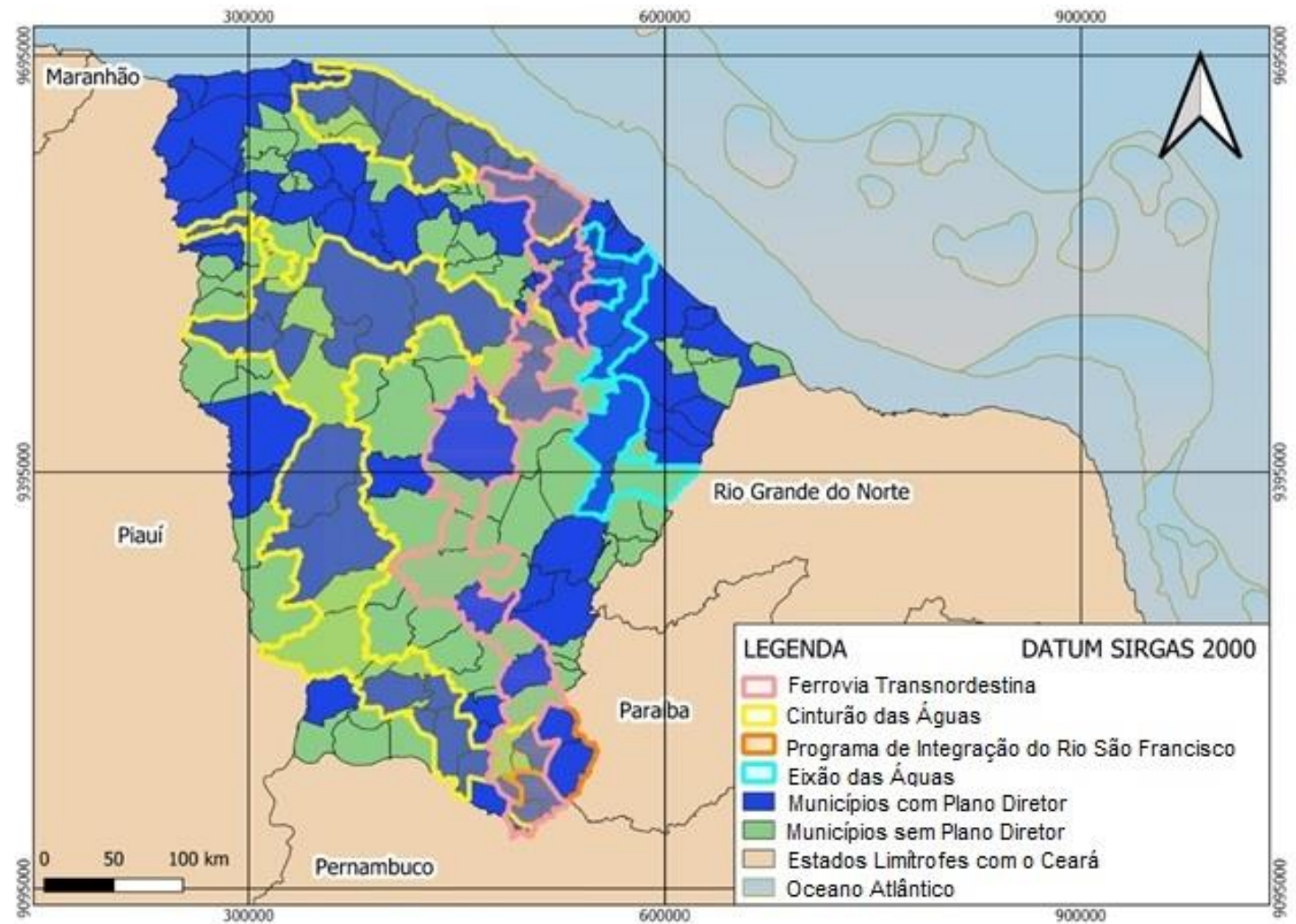

Fonte: elaboração própria a partir de Brasil (2017, 2019b) e Ceará (2018).

Cabe destacar que, mesmo dentre os 50 municípios que possuem Plano Diretor, 32 municípios necessitam revisar seus planos, pois foram constituídos há mais de 10 anos e poderiam utilizar dos recursos desses empreendimentos para a sua revisão, compatibilizando o seu planejamento com os impactos causados por essas grandes intervenções.

5.6. Municípios incluídos no cadastro nacional de municípios com áreas suscetíveis à ocorrência de deslizamentos de grande impacto, inundações bruscas ou processos geológicos ou hidrológicos correlatos

Os municípios inscritos no cadastro nacional com áreas suscetíveis à ocorrência de deslizamentos de grande impacto, inundações bruscas ou processos geológicos ou hidrológicos correlatos devem ser objeto de uma série de ações preventivas, como o mapeamento das áreas de risco; preparação do Plano de Contingência de Proteção e Defesa Civil; instituição de órgãos municipais de defesa civil; desenvolvimento de plano de implantação de obras e serviços para a redução de riscos; criação de mecanismos de controle e fiscalização, para evitar a construção de edificações em áreas 
suscetíveis; e, em especial, a promulgação do Plano Diretor.

Essa exigência, além de prevista no Estatuto da Cidade, também está prevista na Lei $\mathrm{n}^{0} 12.340 / 10$, que determina a formação do cadastro de municípios ${ }^{19}$. No entanto, a regulamentação e implantação do cadastro de municípios, com definição das áreas de risco, até o início do ano de 2020, ainda não tinha sido realizada.

Mesmo assim, a Confederação Nacional dos Municípios (CNM), através da plataforma Observatório dos Desastres Naturais ${ }^{20}$, efetua um levantamento paralelo, baseado nos decretos federais e estaduais, de forma a sistematizar tal medida (Tabela 5).

Tabela 5 - Municípios cearenses com áreas em situação de risco X Plano Diretor

\begin{tabular}{|l|c|c|c|c|c|}
\hline \multirow{2}{*}{ Status do município } & \multirow{2}{*}{$\begin{array}{c}\text { Total de } \\
\text { municípios }\end{array}$} & \multicolumn{3}{c|}{ Possui Plano Diretor } & \multirow{2}{*}{$\begin{array}{c}\text { Não possui } \\
\text { Plano Diretor }\end{array}$} \\
\cline { 3 - 6 } & 115 & 23 & 37 & 60 & 55 \\
\hline Decretada situação de risco & 69 & 14 & 22 & 36 & 69 \\
\hline $\begin{array}{l}\text { Não decretada situação de } \\
\text { risco }\end{array}$ & $\mathbf{1 8 4}$ & $\mathbf{3 7}$ & $\mathbf{5 9}$ & $\mathbf{9 6}$ & $\mathbf{1 2 4}$ \\
\hline Total & & & & & \\
\hline
\end{tabular}

Fonte: CNM (2019).

Conforme os dados apresentados na Tabela 5, no Estado do Ceará, no ano de 2019, 115 municípios encontravam-se em situação de riscos, sendo 109 referentes à seca. Desses 115 municípios, apenas 60 possuíam Plano Diretor, sendo que 37 necessitam ser revisados em virtude do período estipulado no Estatuto da Cidade. No entanto, como não foi implantando o referido cadastro pelo Governo Federal, esse item não torna obrigatória a confecção e regulamentação dos Planos Diretores.

\section{Considerações Finais}

O presente artigo foi desenvolvido a partir da análise das seis hipóteses de obrigatoriedade de promulgação de Plano Diretor para os municípios brasileiros, trazidas no art. 41 da Lei $n^{\circ}$ 10.257/01 (Estatuto da Cidade), em especial para os 184 municípios cearenses.

\footnotetext{
${ }^{19}$ No Brasil, o registro oficial de um desastre poderia ocorrer pela emissão de três documentos distintos, não obrigatoriamente dependentes: Formulário de Informações sobre Desastres (Fipe), que substituiu a Notificação Preliminar de Desastre (Nopred) e a Avaliação de Danos (Avadan), ou decreto municipal ou estadual.

${ }^{20}$ O Observatório dos Desastres é um portal desenvolvido pela Confederação Nacional de Municípios para que os gestores municipais possam acompanhar, monitorar e avaliar a implementação da Política Nacional de Proteção e Defesa Civil (PNPDEC) nos municípios brasileiros, a partir do levantamento e compartilhamento de dados e informações das realidades locais (CNM, 2019).
} 
Foram identificados vários marcos sobre o planejamento urbano das cidades brasileiras, mas eles são dispersos e pouco articulados. Portanto, reforça-se a importância do poder público na padronização e compilação dos regramentos sobre o planejamento urbano.

Dentre os 184 municípios cearenses, apenas 94 municípios possuíam Plano Diretor aprovados, sendo que, dentre os 101 municípios com mais de 20 mil habitantes, 79 possuiam o plano; dos 46 municípios em Regiões Metropolitanas, 30 tinham o plano; dos 68 localizados em áreas turísticas, 57 tinham o plano; e, dos 73 municípios inseridos em regiões de impacto de empreendimentos regionais ou nacionais, 49 tinham plano. Além disso, não foi identificado nenhum município que tivesse Plano Diretor que não se enquadrasse em uma das hipóteses anteriores.

Verificou-se que a maioria dos municípios que tinham Planos Diretores careciam de revisão, conforme estabelecido no $\$ 3^{\circ}$ do artigo 30 do Estatuto da Cidade. Dos 94 Planos Diretores existentes nos municípios cearenses, 59 precisam ser revisados, pois foram instituídos há mais de 10 anos, alguns com data de elaboração de mais de 20 anos sem revisão. Segundo Santos Junior e Montandon (2011), no período de 2005 a 2006, o Ministério das Cidades realizou uma ampla campanha nacional para mobilização e sensibilização de gestores públicos e da sociedade para a preparação dos Planos Diretores, o que pode ter estimulado a instituição, naquela época, nos municípios cearenses.

Além disso, para os municípios pertencentes a uma das três Regiões Metropolitanas do Estado do Ceará, existem os Planos de Desenvolvimento Urbanos Integrados, que foram regulamentados posteriormente a muitos dos Planos Diretores existentes, sendo necessária, assim, uma revisão desses Planos Diretores a fim de manter uma compatibilização entre ambos.

Ao considerarmos que apenas 35 dos 184 municípios cearenses estavam com seus Planos Diretores atualizados, de acordo com o prazo máximo de revisão de 10 anos, percebe-se que existe uma grande dificuldade dos gestores municipais em desenvolverem adequadamente e aprovarem os mesmos.

Verifica-se, portanto, que existem uma série de barreiras que dificultam a realização do processo de confecção e instituição do Plano Diretor, desde barreiras relacionadas à capacidade técnica e operacional, para efetuar o levantamento das 
informações e promover a devida participação social; até as relacionadas ao enfrentamento político-partidário, que, muitas vezes, impede que o processo flua adequadamente, perpassando diversas gestões, sem que haja um entendimento sobre as questões acerca do desenvolvimento urbano do território de um município.

Também foram identificados casos, entre as hipóteses estabelecidas no artigo 41 do Estatuto da Cidade, que não estão regulamentados, sendo eles: obrigatoriedade para municípios integrantes de áreas de especial interesse turístico e para municípios incluídos no cadastro nacional de municípios com áreas suscetíveis à ocorrência de deslizamentos de grande impacto, inundações bruscas ou processos geológicos ou hidrológicos correlatos. É importante salientar que essa ausência de regulamentação dificulta a implementação desses planos e acaba por enfraquecer o planejamento urbanístico, no contexto da governança municipal, bem como aumentar o número de municípios que deveriam obrigatoriamente ter seus planos diretores elaborados.

Verificou-se também a necessidade relevante da adaptação dos municípios cearenses às condições climáticas em que se encontram. Haja vista que, dos 184 municípios, 115 já decretaram, em algum momento do passado, estado de calamidade em virtude de seca. Alinhado a isso também está o fato de que grande parte das obras regionais está atrelada à política pública de segurança hídrica. No entanto, o que se percebeu foi que, mesmo enfrentando uma crise hídrica constante, desses 115 municípios, apenas $58(50 \%)$ possuíam Plano Diretor, e desses, 35 estavam desatualizados.

Assim, dentre os casos estabelecidos no Estatuto da Cidade, existe ainda a hipótese em que o poder público municipal pretenda utilizar os instrumentos previstos no $\S 4^{\circ}$ do art. 182 da Constituição Federal, caso em que a aplicação desses instrumentos torna-se discricionária. No entanto, o cumprimento da função social da cidade é vinculativa, ou seja, essa hipótese deveria necessariamente ocorrer e ser cobrada de todos pelos gestores municipais em todos os municípios.

Ainda, verificou-se que vários municípios cearenses (90) não possuem Plano Diretor, mesmo existindo obrigação legal, deixando os gestores passíveis de punição e as cidades sem um ordenamento urbanístico que viabilize seu desenvolvimento adequado. De forma geral, pode-se verificar que muitos municípios cearenses possuem o Plano Diretor aprovado, mas que os mesmos estão desatualizados, já que o prazo 
máximo, exigido em lei, para que ocorra a revisão é de 10 anos.

Portanto, pelo que foi apresentado aqui, podem-se considerar como problemas enfrentados nas cidades sem Plano Diretor: o crescimento desordenado da cidade; a falta de participação social para a escolha das prioridades nas ações estruturais dentro das cidades; entre outros. Isso acaba gerando um aumento na disparidade social, impactando na qualidade de vida, em especial da população mais carente.

Por fim, destaca-se a dificuldade em compilar todas as informações apresentadas neste artigo, em virtude da multisetorialidade que envolve o referido tema, fazendo com que fosse necessário consultar vários bancos de dados, onde os dados podem estar desatualizados em virtude da falta de informações das prefeituras e dos demais entes responsáveis pelas ações efetuadas.

\section{Referências}

AlMEIDA, L. F. G. Grandes empreendimentos econômicos como financiadores de Planos Diretores em Minas Gerais: uma real alternativa? In: ENCONTRO NACIONAL DA ASSOCIAÇÃo NACIONAL DE PÓS-GRADUAÇÃO E PESQuisa EM Planejamento URbano E Regional, 17., 2017, São Paulo. Anais... São Paulo: Anpur, 2017. 21p. Disponível em: http://anpur.org.br/xviienanpur/principal/publica coes/XVII.ENANPUR_

Anais/ST_Sessoes_Tematicas/ST\%202/ST\%20

2.2/ST\%202.2-04.pdf. Acesso em: 26 mar. 2020.

Bitoun, J.; MiRAnda, L. Desenvolvimento $e$ cidades no Brasil. Contribuições para o debate sobre as políticas territoriais. Recife, PE: FASE: Observatório das Metrópoles, 2009. 194p. Disponível em: https://www.fundaj.gov.br/images/stories/cieg/a rtigos/livrodesenvole cidadesnobrasil.pdf. Acesso em: 10 set. 2020.

BRASIL. Lei Complementar $n^{\circ} 14$, de 08 de junho de 1973. Estabelece as Regiões Metropolitanas de São Paulo, Belo Horizonte, Porto Alegre, Recife, Salvador, Curitiba, Belém e Fortaleza. Brasília, DF: Presidência da República, 1973. Disponível em: http://www.planalto.gov.br/ccivil_03/leis/lcp/Lc p14.htm. Acesso em: 26 dez. 2019.

Lei $n^{\circ}$ 6.513, de 20 de dezembro de 1977. Dispõe sobre a criação de Áreas Especiais e de Locais de Interesse Turístico; sobre o Inventário com finalidades turísticas dos bens de valor cultural e natural; acrescenta inciso ao art. $2^{\circ}$ da Lei $\mathrm{n}^{\circ} 4.132$, de 10 de setembro de 1962; altera a redação e acrescenta dispositivo à Lei $\mathrm{n}^{\circ} 4.717$, de 29 de junho de 1965; e dá outras providências. Brasília, DF: Presidência da República, 1977. Disponível em: http://www.planalto.gov.br/ ccivil_03/leis/16513.htm. Acesso em: 26 dez. 2019.

Decreto $n^{\circ} 86.176$, de 06 de julho de 1981. Regulamenta a Lei ${ }^{\circ} 6.513$, de 20 de dezembro de 1977, que dispõe sobre a criação de Áreas Especiais e de Locais de Interesse Turístico e dá outras providências. Brasília, DF: Presidência da República, 1981. Disponível em: http://www.planalto.gov.br/ccivil_03/decreto/ D86176.htm. Acesso em: 26 dez. 2019.

[Constituição (1988)]. Constituição da República Federativa do Brasil de 1988. Brasília, DF: Presidência da República, [2019]. Disponível em: http://www.planalto.gov.br/ccivil_03/Constituic ao/Constituiçao.htm. Acesso em: 1 jun. 2020.

Lei $n^{\circ}$ 10.257, de 10 de julho de 2001. Regulamenta os arts. 182 e 183 da Constituição Federal, estabelece diretrizes gerais da política urbana e dá outras providências. Brasília, DF: Presidência da República, 2001. Disponível em: http://www.planalto.gov.br/ccivil_03/leis/ 
leis_2001/110257.htm. Acesso em: 26 dez. 2019.

Estatuto da Cidade: guia para implementação pelos municípios e cidadãos. 2 . ed.

Brasília, DF: Câmara dos Deputados, Coordenação de Publicações, 2002. Disponível em: https://polis.org.br/publicacoes/estatuto-dacidade-guia-para-implementacao-pelosmunicipios-e-cidadaos/. Acesso em: 11 set. 2020 .

Resolução $n^{\circ} 22$, de 06 de dezembro de
E2006. Emitir orientações quanto à
regulamentação dos procedimentos para
aplicação dos recursos técnicos e financeiros,
para elaboração do Plano Diretor dos
municípios inseridos em área de influência de
empreendimentos ou atividades com
significativo impacto ambiental, de âmbito
regional ou nacional, com referência nas
diretrizes constantes dos incisos II, IX e XIII do
art. 2 e inciso V do art. 41, do Estatuto da
Cidade. Brasília, DF: Concidades,
2006. Disponível em:
https://www.cidades.gov.br/images/stories/Arqu
ivosCidades/ArquivosPDF/Resolucoes/Resoluc
aoRecomendada/resolucao-22-2006. pdf.
Acesso em: 26 fev. 2020.

Lei $n^{\circ}$ 11.771, de 17 de setembro de 2008. Dispõe sobre a Política Nacional de Turismo, define as atribuições do Governo Federal no planejamento, desenvolvimento e estímulo ao setor turístico; revoga a Lei no 6.505, de 13 de dezembro de 1977, o DecretoLei no 2.294, de 21 de novembro de 1986, e dispositivos da Lei no 8.181 , de 28 de março de 1991; e dá outras providências. Brasília, DF: Presidência da República, 2008. Disponível em: http://www.planalto. gov.br/ccivil_03/_Ato2007-

2010/2008/Lei/L11771.htm. Acesso em: 26 dez. 2019.

Lei $n^{\circ} 12.340$, de 1 de dezembro de 2010. Dispõe sobre as transferências de recursos da União aos órgãos e entidades dos Estados, Distrito Federal e Municípios para a execução de ações de prevenção em áreas de risco de desastres e de resposta e de recuperação em áreas atingidas por desastres e sobre o Fundo Nacional para Calamidades Públicas, Proteção e Defesa Civil; e dá outras providências. Brasília, DF: Presidência da República, 2010. Disponível em:
http://www.planalto.gov.br/ccivil_03/_Ato2007 -2010/2010/Lei/L12340.htm. Acesso em: 26 dez. 2019.

Lei $n^{\circ}$ 12.608, de 10 de abril de 2012. Institui a Política Nacional de Proteção e Defesa Civil - PNPDEC; dispõe sobre o Sistema Nacional de Proteção e Defesa Civil - Sinpdec e o Conselho Nacional de Proteção e Defesa Civil - Conpdec; autoriza a criação de sistema de informações e monitoramento de desastres; altera as Leis $n^{\circ} \mathrm{s} 12.340$, de $1^{\circ}$ de dezembro de 2010, 10.257, de 10 de julho de 2001, 6.766, de 19 de dezembro de $1979,8.239$, de 4 de outubro de 1991, e 9.394, de 20 de dezembro de 1996; e dá outras providências. Brasília, DF: Presidência da República, 2012. Disponível em: http://www.planalto.gov.br/ccivil_03/_Ato2011 -2014/2012/Lei/ L12608.htm\#art26. Acesso em: 10 set. 2020 .

Lei $n^{\circ} 13.089$, de 12 de janeiro de 2015. Institui o Estatuto da Metrópole, altera a Lei $\mathrm{n}^{\circ}$ 10.257, de 10 de julho de 2001, e dá outras providências. Brasília, DF: Presidência da República, 2015a. Disponível em:

http://www.planalto.gov.br/ccivil_03/_ato20152018/2015/lei/113089.htm. Acesso em: $26 \mathrm{dez}$. 2019.

Mapa do Turismo. Brasília, DF: Ministério do Turismo, 2015b. Disponível em: http://www.turismo.gov.br/publicacoes/item/83mapa-do-turismo-brasileiro-2013.html. Acesso em: 22 mar. 2020.

Mapa do Turismo Brasileiro 2016. Brasília, DF: Ministério do Turismo, 2016. 21p. Disponível em: http://www.turismo.gov.br/publicacoes/item/83mapa-do-turismo-brasileiro-2013.html. Acesso em: 22 mar. 2020.

Ferrovia Transnordestina. Brasília, DF: Ministério dos Transportes, Portos e Aviação Civil, 2017. 15p. Disponível em: http://legis.senado.leg.br/sdleggetter/documento/download/ 529b78a4-3b204d3f-b37c-df1ac8d6bcd8. Acesso em: 29 mar. 2020 .

Guia para Elaboração e Revisão de Planos Diretores. Brasília, DF: Ministério do Desenvolvimento Regional (SDRU-MDR); Ministério do Meio Ambiente (SQA-MMA); Cooperação para o Desenvolvimento Sustentável Brasil-Alemanha (GIZ - Projeto Andus), 2020. 21p. Disponível em: 
http://www.capacidades.gov.br/biblioteca/detalh $\mathrm{ar} / \mathrm{id} / 368 /$ titulo/guia-para-elaboracao-e-revisaode-planos-diretores. Acesso em: 12 set. 2020.

CAldas, M. F. Política urbana, ação governamental e a utopia da reforma urbana no Brasil. Tese de Doutorado em Arquitetura e Uranismo. Escola de Arquitetura. Universidade Federal de Minas Gerais. Belo Horizonte, MG: UFMG, 2015. 271p. Disponível em: https://repositorio.ufmg.br/bitstream/1843/MM MD-A86J5X/1/tese_maria_caldas_vers_ofinal. pdf. Acesso em: 14 set. 2020.

CEARÁ. Lei Estadual $n^{o} 13.875$, de 07 de fevereiro de 2007. Dispõe sobre o Modelo de Gestão do Poder Executivo, altera a estrutura da Administração Estadual, promove a extinção e criação de cargos de direção e assessoramento superior, e dá outras providências. Fortaleza, CE: Governo do Estado do Ceará, 2007. Disponível em: https://belt.al.ce.gov.br/index.php/legislacao-doceara/organizacao-tematica/trabalhoadministracao-e-servico-publico/item/4932-lein-13-875-de-07-02-07-d-o-de-07-02-07oriundo-do-projeto-de-lei-n-6-877-07-1executivo. Acesso em: 17 jan. 2020.

Lei Estadual $n^{\circ} 14.558$, de 21 de dezembro de 2009. Cria o Conselho Estadual das Cidades e dá outras providências. Fortaleza, CE: Governo do Estado do Ceará, 2009. Disponível em: belt.al.ce.gov.br > index.php > item > download. Acesso em: 17 jan. 2020.

Histórico. Site da Secretaria das Cidades. Fortaleza, CE: Governo do Estado do Ceará, Secretaria das Cidades do Estado Do Ceará, [2016]. Disponível em: < https://www.cidades.ce.gov.br/a-secretaria-2/>. Acesso em: 17 mar. 2020.

Plano de Ações Estratégicas de Recursos Hídricos do Ceará. Fortaleza, CE: Governo do Estado do Ceará, Secretaria de Recursos Hídricos - SRH, 2018. 171 p. Disponível em:

https://www.srh.ce.gov.br/wp-

content/uploads/sites/90/2018/07/PLANO-DEACOES-ESTRATEGICAS-DE-RECURSOSHIDRI COS-CE_2018.pdf. Acesso em: 10 abr. 2020.

Plano Diretor Municipal - PDM. Site da Secretaria das Cidades. Fortaleza, CE: Governo do Estado do Ceará, Secretaria das Cidades do Estado Do Ceará, [2019].
Disponível em: https://www.cidades.ce.gov.br/plano-diretormunicipal-pdm/. Acesso em: 17 mar. 2020.

CONFEDERAÇÃO NACIONAL DOS MunicíPIOS (CNM). Observatório dos Desastres Naturais. Brasília, DF: CNM, 2019. Disponível em: http://www.desastres.cnm.org.br/. Acesso em: 15 fev. 2020.

DIAS, M. I. S. Gestão urbana: entraves, desafios e avanços na implementação dos planos diretores: estudo de caso Barra do Piraí-RJ. Dissertação de Mestrado em Urbanismo. Centro de Ciências Exatas, Ambientais e de Tecnologia. Campinas, SP, 2011. Disponível em: $\quad$ http://tede.bibliotecadigital.puccampinas.edu.br:8080/jspui/handle/tede/93.

Acesso em 11 set. 2020.

FAvarÃo, C. B.; Costa, M. A. - Cap 3. Governança e políticas nacionais urbanas: capacidade e desenvolvimento institucional. In: Costa, M. A.; MAgalhães, M. T. Q.; FAVARÃo, C. B. (Orgs.). A nova agenda urbana $e$ o Brasil: insumos para sua construção $\mathrm{e}$ desafios a sua implementação. Brasília: Ipea, 2018.

FONSECA, J. J. S. Metodologia da pesquisa científica. Ceará: Universidade Estadual do Ceará, 2002.

FreitAs, A. L.; BARBosA, K. C. S. O impacto do Plano Diretor Municipal na mobilidade da cidade: um estudo de caso na cidade de Goianésia/GO. Trabalho de Conclusão de Curso de Engenharia Civil. Faculdade Evangélica de Goianésia. Goianésia: GO, 2019. Disponível em:

http://repositorio.aee.edu.br/bitstream/aee/1682/ 1/2019_1_ANA\%20LUISA_KELLEN.pdf.

Acesso em: 13 set. 2020.

GIL, A. C. Métodos e técnicas de pesquisa social. 5. ed. São Paulo: Atlas, 1999.

Goulart, J. O.; Terci, E. T.; Otero, E. V. Participação política e gestão urbana sob o Estatuto da Cidade. URBE. Revista Brasileira de Gestão Urbana (Brazilian Journal of Urban Management), v. 7, n. 1, p. 122-135, jan./abr. 2015.

HARVEY, D. A justiça social e a cidade. São Paulo: Hucitec, 1980.

INSTITUTO BRASILEIRO DE GEOGRAFIA E 
EstatístiCA (IBGE). Contagem populacional 2019. Rio de Janeiro, RJ: IBGE, 2019a. Disponível em: https://cidades.ibge.gov.br/brasil/mg/contagem/ panorama. Acesso em: $20 \mathrm{fev} .2020$.

\footnotetext{
Pesquisa de Informações Básicas Municipais - Munic 2018. Rio de Janeiro: IBGE, 2019b. Disponível em: https://www.ibge.gov.br/estatisticas/sociais/edu cacao/10586-pesquisa-de-informacoes-basicasmunicipais.html?=\&t=o-que-e. Acesso em: 19 fev. 2020.
}

INSTITUTO DE PESQUisA E EsTRATÉGIA ECONÔMICA DO CEARÁ (IPECE). Ceará em mapas: infra-estrutura. Fortaleza, Ceará: Ipece, [2018]. Disponível em: http://www2.ipece.ce.gov.br/atlas/capitulo4/ind ex.htm. Acesso em: 10 jan. 2020.

MCCALL, M. K.; DunN, C. E. Geo-information tools for participatory spatial planning: Fulfilling the criteria for 'good' governance? Geoforum, v. 43, n. 1, p. 81-94, jan. 2012. Disponível em:

https://www.sciencedirect.com/science/article/a bs/pii/S0016718511001369. Acesso em: 13 set. 2020.

MOREIRA, H. F. O plano diretor e as funções sociais da cidade. Rio de Janeiro, RJ: CPRM. Serviço Geológico do Brasil, 2008. Disponível em: https://goo.gl/1GsGAE. Acesso em: 11 set. 2020 .
NAZARETh, P. A. Planos diretores e instrumentos de gestão urbana e ambiental no Estado do Rio de Janeiro. Revista do Serviço Público (RSP), v. 69, n. 1, p. 211-240, jan./mar. 2018. Brasília, DF: RSP, 2018. Disponível em: https://repositorio.enap.gov.br/bitstream/1/3269/ 1/PLANOS $\%$ 20DIRETORES\%20E\%20INSTR UMENTOS\%20DE\%20GEST\%C3\%830\%20U RBANA $\% 20 \mathrm{E} \% 20 \mathrm{AMBIENTAL} \% 20 \mathrm{NO} \% 20 \mathrm{E}$ STADO\%20DO\%20RIO\%20DE\%20JANEIRO .pdf. Acesso em: 13 set. 2020.

SAntos Junior, O. A.; Montandon, D. T. Os planos diretores municípais pós-estatuto da cidade: balanço crítico e perspectivas. Rio de Janeiro, RJ: Letra Capital: Observatório das Cidades: IPPUR/UFRJ, 2011. Disponível em: https://bibliotecadigital.seplan.planejamento. gov.br/handle/iditem/302. Acesso em: 10 set. 2020 .

SILva, J. A. Direito urbanístico brasileiro. São Paulo: Malheiros, 2010. 6 Edição. 468p.

SouZA, C. Regiões metropolitanas: reforma do regime político e vazio de governança. In: DINIZ, E. (Ed.). Globalização, Estado $e$ desenvolvimento: dilemas do Brasil no novo milênio. Rio de Janeiro: FGV, 2007. p. 235-261.

VALERY, F. D.; BRAGA JUNIOR, S. A. M. Estatuto da Metrópole e Estatuto da Cidade: instrumentos de gestão e planejamento urbano. In: SEMINÁRIO DE PESQUISA DO CCSA/UFRN, 20., 2015, Rio Grande do Norte. Anais... 2015. Natal - RN: CCSA/UFRN, 2015. 12p.

\section{Francisco Alberto de Castro Neto}

iD https://orcid.org/0000-0002-4106-5893

Mestre em Saúde Pública pela Escola Nacional de Saúde Pública da Fiocruz. Bacharel em Engenharia Civil pela Universidade Federal do Ceará. Secretaria das Cidades do Governo do Estado do Ceará.

E-mail: alberto.ec@hotmail.com

\section{Ana Elisa Pinheiro Campêlo de Castro}

\section{iD https://orcid.org/0000-0001-9138-9717}

Mestre em Engenharia de Transportes pela Universidade Federal do Ceará. Bacharel em Arquitetura e Urbanismo pela Universidade Federal do Ceará. Instituto de Planejamento de Fortaleza.

E-mail: anaelisacampelo@hotmail.com 
Apêndice A

\begin{tabular}{|c|c|c|c|c|c|c|c|}
\hline Município & $\begin{array}{c}\text { Plano } \\
\text { Diretor }\end{array}$ & $\begin{array}{c}\text { Aprovação } \\
\text { Lei }\end{array}$ & População & $\begin{array}{l}\text { Região } \\
\text { Metrop. }\end{array}$ & $\begin{array}{c}\text { Área } \\
\text { Turística }\end{array}$ & $\begin{array}{c}\text { Emp. grande } \\
\text { impacto }\end{array}$ & Calamidade \\
\hline Fortaleza & Sim & 2009 & 2.669 .342 & RMF & SIM & & SIM \\
\hline Caucaia & Sim & 2001 & 361.400 & RMF & SIM & SIM & SIM \\
\hline Juazeiro do Norte & Sim & 2000 & 274.207 & RMC & SIM & & \\
\hline Maracanaú & Sim & 2012 & 227.886 & RMF & SIM & & SIM \\
\hline Sobral & Sim & $2000 / 2008$ & 208.935 & RMS & SIM & & SIM \\
\hline Crato & Sim & $2005 / 2012$ & 132.123 & RMC & SIM & SIM & SIM \\
\hline Itapipoca & Sim & $2000 / 2013$ & 129.358 & & SIM & SIM & SIM \\
\hline Maranguape & Sim & 2000 & 128.978 & RMF & & SIM & SIM \\
\hline Iguatu & Sim & $2009 / 2017$ & 102.498 & & SIM & SIM & SIM \\
\hline Quixadá & Não & 2000 & 87.728 & & SIM & SIM & SIM \\
\hline Pacatuba & Sim & 2007 & 83.432 & RMF & SIM & SIM & \\
\hline Quixeramobim & Sim & 2000 & 81.082 & & SIM & SIM & SIM \\
\hline Aquiraz & Sim & 2011/2017 & 80.271 & RMF & SIM & & SIM \\
\hline Russas & Sim & 2000 & 78.194 & & SIM & & SIM \\
\hline Canindé & Sim & $2000 / 2006$ & 76.997 & & SIM & SIM & SIM \\
\hline Tianguá & Sim & $2004 / 2018$ & 75.946 & & SIM & & \\
\hline Crateús & Sim & $2001 / 2011$ & 75.074 & & SIM & & SIM \\
\hline Aracati & Sim & $2001 / 2009$ & 74.547 & & SIM & & SIM \\
\hline Pacajus & Sim & 2018 & 72.203 & RMF & SIM & SIM & SIM \\
\hline Cascavel & Sim & 2000 & 71.743 & RMF & SIM & SIM & SIM \\
\hline Icó & Sim & 2003 & 68.018 & & SIM & & SIM \\
\hline Horizonte & Sim & 2000 & 67.337 & RMF & & SIM & SIM \\
\hline Camocim & Sim & $2000 / 2011$ & 63.661 & & SIM & & \\
\hline Acaraú & Sim & 2011 & 62.641 & & SIM & SIM & \\
\hline Morada Nova & Sim & $2000 / 2018$ & 61.890 & & SIM & SIM & SIM \\
\hline Viçosa do Ceará & Sim & 2008 & 60.889 & & SIM & & SIM \\
\hline Barbalha & Sim & 2000 & 60.781 & RMC & SIM & SIM & \\
\hline Limoeiro do Norte & Sim & 2018 & 59.540 & & SIM & & SIM \\
\hline Tauá & Sim & 2016 & 58.859 & & SIM & SIM & SIM \\
\hline Trairi & Sim & $2009 / 2010$ & 55.918 & RMF & SIM & SIM & \\
\hline Granja & Sim & 2010 & 54.748 & & & & \\
\hline Boa Viagem & Não & & 54.470 & & & & SIM \\
\hline Acopiara & Não & & 54.270 & & & SIM & SIM \\
\hline Eusébio & Sim & $2008 / 2017$ & 53.618 & RMF & SIM & & SIM \\
\hline Beberibe & Sim & 2007 & 53.573 & & SIM & & SIM \\
\hline Itapajé & Sim & 2001 & 52.675 & & & & SIM \\
\hline Brejo Santo & Sim & 2003 & 49.477 & & SIM & SIM & \\
\hline $\begin{array}{c}\text { São Gonçalo do } \\
\text { Amarante }\end{array}$ & Sim & 2013 & 48.422 & RMF & SIM & SIM & SIM \\
\hline Mauriti & Sim & $2007 / 2015$ & 47.962 & & & SIM & \\
\hline São Benedito & Sim & 2000 & 47.903 & & SIM & & \\
\hline Mombaça & Não & & 43.797 & & & & SIM \\
\hline Santa Quitéria & Sim & 2010 & 43.703 & & & SIM & SIM \\
\hline Amontada & Sim & $2009 / 2012$ & 43.452 & & SIM & SIM & \\
\hline
\end{tabular}




\begin{tabular}{|c|c|c|c|c|c|c|c|}
\hline Município & $\begin{array}{l}\text { Plano } \\
\text { Diretor }\end{array}$ & $\begin{array}{l}\text { Aprovação } \\
\text { Lei }\end{array}$ & População & $\begin{array}{l}\text { Região } \\
\text { Metrop. }\end{array}$ & $\begin{array}{c}\text { Área } \\
\text { Turística }\end{array}$ & $\begin{array}{l}\text { Emp. grande } \\
\text { impacto }\end{array}$ & Calamidade \\
\hline Pedra Branca & Sim & $2009 / 2014$ & 43.258 & & & & SIM \\
\hline Ipu & Sim & 2001 & 41.964 & & SIM & SIM & SIM \\
\hline Itarema & Sim & 2008 & 41.826 & & SIM & SIM & \\
\hline Várzea Alegre & Não & & 40.721 & & SIM & & SIM \\
\hline $\begin{array}{l}\text { Guaraciaba do } \\
\text { Norte }\end{array}$ & Não & & 40.642 & & SIM & & \\
\hline Massapê & Sim & 2012 & 38.737 & RMS & & & \\
\hline Ipueiras & Sim & 2006 & 38.166 & & & SIM & \\
\hline Itaitinga & Sim & 2002 & 37.980 & RMF & SIM & SIM & SIM \\
\hline Pentecoste & Sim & 2009 & 37.751 & & & & SIM \\
\hline Baturité & Sim & 2001 & 35.750 & & SIM & SIM & \\
\hline Missão Velha & Não & & 35.393 & RMC & & SIM & SIM \\
\hline Paracuru & Sim & $2009 / 2017$ & 35.076 & RMF & SIM & SIM & \\
\hline Ubajara & Sim & 2004 & 34.792 & & SIM & SIM & \\
\hline Jaguaribe & Sim & 2019 & 34.682 & & SIM & & SIM \\
\hline Jaguaruana & Não & 2019 & 33.705 & & & & SIM \\
\hline Paraipaba & Sim & 2009 & 32.744 & RMF & SIM & SIM & \\
\hline Bela Cruz & Sim & 2008 & 32.591 & & & SIM & SIM \\
\hline Santana do Acaraú & Sim & 2007 & 32.452 & RMS & & & SIM \\
\hline Nova Russas & Sim & 2001 & 32.328 & & & SIM & SIM \\
\hline Parambu & Não & & 31.521 & & & & SIM \\
\hline $\begin{array}{c}\text { Lavras da } \\
\text { Mangabeira }\end{array}$ & Sim & 2018 & 31.508 & & & SIM & SIM \\
\hline $\begin{array}{l}\text { Tabuleiro do } \\
\text { Norte }\end{array}$ & Sim & 2006 & 30.697 & & & & SIM \\
\hline Redenção & Sim & $2000 / 2008$ & 29.053 & & SIM & SIM & \\
\hline Novo Oriente & Sim & 2016 & 28.607 & & & & \\
\hline Milagres & Sim & 2006 & 27.512 & & & SIM & SIM \\
\hline Campos Sales & Sim & 2002 & 27.426 & & & & SIM \\
\hline Marco & Não & & 27.361 & & & SIM & \\
\hline Jardim & Sim & 2006 & 27.174 & RMC & & & SIM \\
\hline Caririaçu & Sim & 2006 & 26.965 & RMC & & & SIM \\
\hline Aracoiaba & Sim & 2006 & 26.469 & & & SIM & SIM \\
\hline Tamboril & Não & & 26.251 & & & SIM & SIM \\
\hline Independência & Sim & 2006 & 26.178 & & & SIM & SIM \\
\hline Guaiúba & Sim & $1998 / 2001$ & 26.064 & RMF & & SIM & \\
\hline Ocara & Sim & 2008 & 25.703 & & & SIM & SIM \\
\hline Cedro & Não & & 25.557 & & & SIM & SIM \\
\hline Senador Pompeu & Não & & 25.496 & & & SIM & SIM \\
\hline Ibiapina & Sim & 2006 & 24.997 & & SIM & & \\
\hline Jucás & Não & & 24.833 & & & & SIM \\
\hline Cruz & Sim & 2008 & 24.827 & & SIM & & \\
\hline Aurora & Não & & 24.654 & & & SIM & \\
\hline Forquilha & Sim & 2008 & 24.218 & RMS & & & \\
\hline Irauçuba & Sim & 2007 & 24.156 & & & & SIM \\
\hline Assaré & Sim & 2006 & 23.417 & & SIM & SIM & SIM \\
\hline
\end{tabular}




\begin{tabular}{|c|c|c|c|c|c|c|c|}
\hline Município & $\begin{array}{c}\text { Plano } \\
\text { Diretor }\end{array}$ & $\begin{array}{l}\text { Aprovaçãa } \\
\text { Lei }\end{array}$ & População & $\begin{array}{l}\text { Região } \\
\text { Metrop. }\end{array}$ & $\begin{array}{c}\text { Área } \\
\text { Turística }\end{array}$ & $\begin{array}{l}\text { Emp. grande } \\
\text { impacto }\end{array}$ & Calamidade \\
\hline Coreaú & Sim & 2008 & 23.136 & RMS & & & \\
\hline Barro & Sim & $2007 / 2014$ & 22.680 & & & SIM & \\
\hline Caridade & Não & & 22.547 & & & & SIM \\
\hline Morrinhos & Não & & 22.534 & & & & SIM \\
\hline Barreira & Sim & 1994 & 22.425 & & & & SIM \\
\hline Quixeré & Sim & 2018 & 22.149 & & & & SIM \\
\hline Uruburetama & Não & & 21.850 & & & & \\
\hline Itatira & Não & & 21.647 & & & & SIM \\
\hline Araripe & Não & & 21.600 & & & & SIM \\
\hline Orós & Sim & 2009 & 21.427 & & SIM & & \\
\hline Quiterianópolis & Não & & 21.084 & & & & SIM \\
\hline Catarina & Não & & 20.698 & & & & SIM \\
\hline Pindoretama & Sim & 2018 & 20.567 & RMF & SIM & & SIM \\
\hline Itapiúna & Sim & 2017 & 20.382 & & & SIM & SIM \\
\hline Chorozinho & Sim & 2007 & 20.264 & RMF & SIM & & SIM \\
\hline Hidrolândia & Não & & 19.978 & & & SIM & SIM \\
\hline Icapuí & Não & & 19.934 & & SIM & & SIM \\
\hline Umirim & Não & & 19.825 & & & & SIM \\
\hline $\begin{array}{c}\text { Jijoca de } \\
\text { Jericoacoara }\end{array}$ & Sim & $2009 / 2017$ & 19.816 & & SIM & & \\
\hline Madalena & Não & & 19.691 & & & & SIM \\
\hline Farias Brito & Sim & $2006 / 2008$ & 19.450 & RMC & & SIM & SIM \\
\hline Tejuçuoca & Não & & 19.187 & & SIM & & \\
\hline Cariús & Não & & 18.699 & & & & SIM \\
\hline Reriutaba & Não & & 18.491 & RMS & & SIM & SIM \\
\hline Cariré & Não & & 18.448 & RMS & & & \\
\hline Varjota & Não & & 18.420 & RMS & & & \\
\hline Solonópole & Não & & 18.324 & & SIM & & SIM \\
\hline Banabuiú & Não & & 18.197 & & & & SIM \\
\hline Jaguaretama & Não & & 18.162 & & SIM & & SIM \\
\hline Croatá & Não & & 18.063 & & & & \\
\hline Capistrano & Não & & 17.738 & & & SIM & SIM \\
\hline Santana do Cariri & Não & & 17.700 & RMC & SIM & & SIM \\
\hline Carnaubal & Não & & 17.606 & & & & \\
\hline Aiuaba & Não & & 17.399 & & & SIM & SIM \\
\hline $\begin{array}{c}\text { Monsenhor } \\
\text { Tabosa }\end{array}$ & Não & & 17.234 & & & & SIM \\
\hline Alto Santo & Não & & 17.146 & & & SIM & SIM \\
\hline Piquet Carneiro & Não & & 16.959 & & & SIM & SIM \\
\hline Salitre & Não & & 16.554 & & & & SIM \\
\hline Fortim & Sim & 2017 & 16.480 & & SIM & & \\
\hline Pereiro & Não & & 16.307 & & & & SIM \\
\hline Tururu & Não & & 16.271 & & & & \\
\hline Quixelô & Não & & 16.178 & & & & SIM \\
\hline Saboeiro & Não & & 15.819 & & & & SIM \\
\hline Nova Olinda & Sim & 2009 & 15.565 & RMC & SIM & SIM & SIM \\
\hline
\end{tabular}




\begin{tabular}{|c|c|c|c|c|c|c|c|}
\hline Município & $\begin{array}{c}\text { Plano } \\
\text { Diretor }\end{array}$ & $\begin{array}{l}\text { Aprovaçãa } \\
\text { Lei }\end{array}$ & População & $\begin{array}{l}\text { Região } \\
\text { Metrop. }\end{array}$ & $\begin{array}{c}\text { Área } \\
\text { Turística }\end{array}$ & $\begin{array}{l}\text { Emp. grande } \\
\text { impacto }\end{array}$ & Calamidade \\
\hline Meruoca & Não & & 15.057 & RMS & SIM & & SIM \\
\hline Barroquinha & Sim & 2010 & 15.017 & & SIM & & SIM \\
\hline Porteiras & Sim & 2011 & 14.996 & & & SIM & \\
\hline Acarape & Sim & 2001 & 14.929 & & & SIM & \\
\hline Apuiarés & Não & & 14.600 & & & & \\
\hline Mucambo & Não & & 14.537 & RMS & & SIM & \\
\hline Graça & Não & & 14.399 & RMS & & & \\
\hline Iracema & Não & & 14.297 & & & & SIM \\
\hline Frecheirinha & Não & & 14.072 & RMS & & & \\
\hline Uruoca & Não & & 13.840 & & & & \\
\hline Miraíma & Não & & 13.818 & & & & SIM \\
\hline Choró & Não & & 13.521 & & & SIM & SIM \\
\hline Ibaretama & Não & & 13.353 & & & & SIM \\
\hline Palmácia & Não & & 13.322 & & SIM & SIM & SIM \\
\hline Milhã & Não & & 13.155 & & & & SIM \\
\hline Chaval & Sim & 2013 & 13.069 & & SIM & & SIM \\
\hline São Luís do Curu & Não & & 13.000 & RMF & & & \\
\hline Ibicuitinga & Não & & 12.525 & & & & SIM \\
\hline Ipaumirim & Não & & 12.463 & & & & \\
\hline Poranga & Não & & 12.336 & & & & \\
\hline Pacoti & Sim & 2006 & 12.261 & & SIM & & \\
\hline Paramoti & Não & & 12.226 & & & & SIM \\
\hline Aratuba & Sim & 2004 & 11.847 & & SIM & & \\
\hline Abaiara & Não & & 11.737 & & & SIM & SIM \\
\hline Alcântaras & Não & & 11.714 & RMS & & & \\
\hline Ipaporanga & Não & & 11.593 & & & & SIM \\
\hline Jaguaribara & Sim & 2001 & 11.401 & & SIM & SIM & SIM \\
\hline Martinópole & Não & & 11.233 & & & & \\
\hline Groaíras & Não & & 11.068 & RMS & & & SIM \\
\hline Potengi & Não & & 11.045 & & & & \\
\hline Pires Ferreira & Não & & 10.951 & RMS & & SIM & SIM \\
\hline Ararendá & Não & & 10.935 & & & & \\
\hline Mulungu & Não & & 10.823 & & SIM & & \\
\hline Catunda & Sim & 2017 & 10.342 & & & SIM & SIM \\
\hline $\begin{array}{c}\text { Deputado Irapuan } \\
\text { Pinheiro }\end{array}$ & Não & & 9.625 & & & & SIM \\
\hline Palhano & Não & & 9.386 & & & SIM & SIM \\
\hline Penaforte & Sim & 2007 & 9.077 & & & SIM & \\
\hline Moraújo & Não & & 8.724 & RMS & & & \\
\hline Tarrafas & Não & & 8.592 & & & SIM & SIM \\
\hline Jati & Sim & 2007 & 8.111 & & & SIM & SIM \\
\hline Arneiroz & Não & & 7.840 & & & SIM & SIM \\
\hline Itaiçaba & Não & & 7.827 & & & & \\
\hline Umari & Não & & 7.733 & & & & SIM \\
\hline $\begin{array}{l}\text { São João do } \\
\text { Jaguaribe }\end{array}$ & Não & & 7.645 & & & & \\
\hline
\end{tabular}




\begin{tabular}{|c|c|c|c|c|c|c|c|}
\hline Município & $\begin{array}{c}\text { Plano } \\
\text { Diretor }\end{array}$ & $\begin{array}{c}\text { Aprovação } \\
\text { Lei }\end{array}$ & População & $\begin{array}{l}\text { Região } \\
\text { Metrop. }\end{array}$ & $\begin{array}{c}\text { Área } \\
\text { Turística }\end{array}$ & $\begin{array}{l}\text { Emp. grande } \\
\text { impacto }\end{array}$ & Calamidade \\
\hline Senador Sá & Não & & 7.623 & RMS & & & \\
\hline General Sampaio & Não & & 7.618 & & & & \\
\hline Altaneira & Não & & 7.586 & & & SIM & \\
\hline Antonina do Norte & Não & & 7.353 & & & SIM & SIM \\
\hline Ererê & Não & & 7.198 & & & & \\
\hline Pacujá & Não & & 6.533 & RMS & & & \\
\hline Potiretama & Não & & 6.419 & & & & SIM \\
\hline Baixio & Não & & 6.288 & & & & \\
\hline Guaramiranga & Sim & 2005 & 5.193 & & SIM & & \\
\hline Granjeiro & Não & & 4.844 & & & & \\
\hline
\end{tabular}

Fonte: IBGE (2019a, 2019b), Brasil (2016, 2017), Ceará (2018) e CNM (2019). 